\title{
The Proposed LOSC Implementation Agreement on Areas Beyond National Jurisdiction and its Impact on International Fisheries Law
}

\author{
Professor Richard Barnes \\ University of Hull
}

\begin{abstract}
As the development of an implementation agreement on the conservation and sustainable use of marine biodiversity in areas beyond national jurisdiction gathers pace, it is important to consider how this might impact upon international fisheries law. Although the proposed agreement provides an opportunity to addresses governance gaps both generally and with respect to fisheries, we should not expect too much of it; not least because the inclusion per se of fisheries remains debated by States. Also, positive institutional developments are already occurring beyond this UN process. The proposed implementation agreement should not undermine existing laws, but it is unlikely to leave them untouched. The application of integrated governance principles, and the use of area-based management tools and environmental impact assessment will necessarily influence fisheries regulation in ABNJ. Accordingly, care should be taken to ensure that any innovative governance tools are adapted to existing institutional capacities and circumstances.
\end{abstract}

\section{Keywords}

areas beyond national jurisdiction; international fisheries law; regional fisheries management organizations; LOSC implementation agreement; governance principles; area-based management tools; environmental impact assessment

\section{Introduction ${ }^{1}$}

The United Nations Convention on the Law of the Sea (LOSC) establishes a broad framework for the regulation of our oceans. ${ }^{2}$ However, it is not complete. One such gap concerns the regulation of marine resources in areas beyond national jurisdiction (ABNJ). ${ }^{3}$ States have resorted, inter alia, to the negotiation of implementation agreements' to fill gaps in or resolve problems with LOSC. ${ }^{4}$ Two such agreements have been adopted and now it is likely that a third will emerge to deal with ABNJ. ${ }^{5}$ On 13 February 2015, the Ad-Hoc Open-ended Informal Working Group to study

\footnotetext{
${ }^{1}$ This paper was delivered first at a workshop organized by the K.G. Jebsen Centre for the Law of the Sea at the University of Troms $\varnothing$. My thanks to the Centre and colleagues at the workshop for their support, as well as Philomène Verlaan and David Freestone for their helpful feedback on the paper.

${ }^{2}$ United Nations Convention on the Law of the Sea (Montego Bay, 10 December 1982, in force 16 November 1994), 1833 UNTS 396.

${ }^{3}$ ABNJ refers to the high seas and the Area - the deep seabed beyond the outer limits of the continental shelf.

${ }^{4}$ On the development of the LOSC through a range of mechanisms, see generally, J Barrett and $\mathrm{R}$ Barnes (eds), Law of the Sea: LOSC as a Living Treaty (BIICL, London, 2016).

${ }^{5} 1994$ Agreement relating to the implementation of Part XI of the LOSC of 10 December 1982 (New York, 28 July 1994, in force 28 July 1996), 1836 UNTS 42; The United Nations Agreement for the Implementation of the Provisions of the United Nations Convention on the Law of the Sea of 10 December 1982 relating to the conservation and management of straddling fish stocks and highly migratory fish stocks (New York, 4 August 1995, in force force 11 December 2001) 2167 UNTS 88 (Fish Stocks Agreement or FSA).
} 
issues related to the conservation and sustainable management of marine biological diversity beyond areas of national jurisdiction (BBNJ Working Group) concluded its work and recommended that the United Nations General Assembly (UNGA) initiate a process for the negotiation of an international legally binding instrument on the conservation and sustainable use of BBNJ. ${ }^{6}$ On 19 June 2016, the UNGA accepted this recommendation and initiated this process through the adoption of UNGA Resolution 69/292. ${ }^{7}$ This Resolution established a Preparatory Committee (PrepCom) to make substantive recommendations on the elements of a draft legal text. This was a significant step, the culmination of more than a decade of efforts focused on what is generally accepted to be a major gap in the scope of the LOSC ${ }^{8}$ It is for the UNGA decide whether to convene an intergovernmental conference to consider the recommendations of PrepCom, and elaborate the text of a legally binding instrument. This decision will be taken in 2018, and it is possible that a new agreement will be ready for adoption by 2020 .

Although States generally recognize the need for a global instrument on the conservation and sustainable use of marine biodiversity in ABNJ, this general consensus masks important differences of opinion on the precise scope and content of such an instrument, and of its relationship with existing arrangements. ${ }^{9}$ The process of developing a new agreement "should not undermine existing relevant legal instruments and frameworks and relevant global, regional and sectoral bodies". ${ }^{10}$ As this paper will show, this raised particularly difficult questions in respect of fisheries. Given that there is little agreement beyond the general topics to be covered in the proposed implementing agreement, one must be cautious about speculating too far on what future negotiations may bring. However, one can be reasonably certain that the agreement will articulate some general principles concerning the conservation and use of marine biological resources. It will also address the use of area-based management (ABM) tools, the use of environmental impact assessment (EIA) and mechanisms for capacity-building and technology transfer. For the most part fisheries issues are likely to remain governed by existing instruments. However, the scope of the proposed agreement means that fisheries will not be unaffected. First, many of the governance principles proposed for the prospective $\mathrm{ABNJ}$ implementation agreement (ABNJ IA) are likely to influence or shape the future mandates of regional fisheries management organizations (RFMOs), filling or addressing noted governance gaps. Second, two key elements of the proposed ABNJ IA, i.e., ABM and EIA, necessarily entail some degree of overlap with or accommodation of fishing activities.

\footnotetext{
${ }^{6}$ Letter dated 13 February 2015 from the Co-Chairs of the Ad-Hoc Open-ended Informal Working Group to the President of the UN General Assembly, UN Doc. 69/780, A/69/780, annex, section I.

${ }^{7}$ UNGA Res. 69/292, UN Doc. A/Res/69.292, 6 July 2015.

${ }^{8}$ On the governance gap see: K Gjerde, H Dotinga, S Hart, EJ Molenaar, R Rayfuse and R Warner, Regulatory and Governance Gaps in the International Regime for the Conservation and Sustainable Use of Marine Biodiversity in Areas beyond National Jurisdiction (IUCN, Gland, Switzerland, 2008); K Gjerde, 'High Seas Fisheries Governance: Prospects and Challenges in the 21st Century' in D Vidas and PJ Schei (eds) The World Ocean in Globalisation: Challenges and Responses (Martinus Nijhoff Publishers, Leiden, 2011), 99-113; D Freestone, 'The Final Frontier: The Law of the Sea Convention and Areas beyond National Jurisdiction' in HN Scheiber and M-S Kwon (eds), Securing the Ocean for the Next Generation (Law of the Sea Institute, Berkeley, CA, 2012), 1-15; D Freestone, 'Governance of Areas Beyond National Jurisdiction: An Unfinished Agenda' in Barrett and Barnes supra (n 4) 231265.

${ }^{9}$ This can be drawn from the discussions taking place within the BBNJ Working Group. See the CoChairs' summary of discussions in the Letter of 13 February 2016, supra (n 6), para 14.

${ }^{10}$ UNGA Res. 69/292, supra (n 7), para 3.
} 
This paper examines developments so far, focusing specifically on how they might affect fisheries regulation under international law. ${ }^{11}$ After outlining the context of the ABNJ IA, the paper reviews progress in the UN ABNJ process to date and examines the extent to which fisheries have featured in discussions. Although the debates were not conclusive of how fisheries will be accommodated in the proposed ABNJ IA, some general trends can be detected. This suggests that a broadly integrated approach, which builds on and is complementary to existing measures, will be preferred to radical approaches. The paper then traces these discussions through the work of PrepCom 1. This is followed by an analysis of the potential contents of an ABNJ IA, focusing on those issues most likely to affect fisheries, i.e., governance principles, $\mathrm{ABM}$ and EIA. Within the ABNJ IA, the articulation and institutional support measures for governance principles will be absolutely critical. In the final section, the potential effects of this approach are assessed in existing fisheries regulation. Here I suggest that there will need to be some adaptation of RFMOs (in terms of substantive principles, expanded remits), efforts outside the IA to close institutional and substantive gaps (new RFMOs), and more formalized mechanisms for institutional cooperation and decision-making.

\section{Context To The Proposed Implementing Agreement}

\section{The LOSC and ABNJ}

The LOSC is a product of its time and so designed to deal with matters of which the negotiating States were then aware. This did not include the issue of marine genetic resources (MGR), biological diversity or indeed many issues related to the governance of the marine environment of ABNJ. Part XI of the LOSC was designed mainly to deal with mineral resources. That said, many of the LOSC's provisions were drafted in a way that would allow them to adapt to new situations. ${ }^{12}$ Despite this flexibility, the discovery of the existence of valuable marine resources with the potential to be exploited for their genetic potential, along with a growing awareness of the complex nature of deep sea ecosystems, has challenged the suitability of the LOSC as a self-contained regime for ABNJ. Much of this has focused on the tension between States holding to the applicability of the principles of freedom of the high seas and States advocating the application of the principle of the common heritage of mankind (CHM) to the resources constituting marine biological diversity. ${ }^{13}$

\footnotetext{
${ }^{11}$ For a general review of developments, see R Long and M Chaves, 'Anatomy of a new international instrument for marine biodiversity beyond national jurisdiction. First impressions of the preparatory process' (2015) 6 Environmental Liability 213-229.

${ }^{12}$ See for example, SV Scott, 'The LOS Convention as a Constitutional Regime for the Oceans' in AG Oude Elferink (ed), Stability and Change in the Law of the Sea: The Role of the LOS Convention (Martinus Nijhoff 2005) 9-38; A Boyle, 'Further Development of the 1982 Convention on the Law of the Sea' in D Freestone, R Barnes and D Ong (eds), Law of the Sea. Progress and Prospects (Oxford University Press 2006) 40-62; Barrett and Barnes, supra (n 4).

${ }^{13}$ This is widely discussed in the literature. See for example, D Tladi, 'Genetic Resources, Benefit Sharing, and the Law of the Sea: the Need for Clarity' (2007) 13(3) Journal of International Maritime Law 183-193; AG Oude Elferink, 'The Regime of the Area: Delineating the Scope of Application of the Common Heritage Principle and of Freedom of the High Seas' (2007) 22(1) IJMCL 143-176.
} 
UN-led Consideration of Marine Biodiversity - The BBNJ Working Group In 2004, the UNGA established the BBNJ Working Group. ${ }^{14}$ The BBNJ Working Group would survey past and present activities of the UN and other intergovernmental organizations (IGOs), examine scientific, technical, economic, legal, environmental, socio-economic and other aspects of these issues. This would provide the basis for more detailed studies by States of these issues, and ultimately lead to recommendations on how to improve cooperation and coordination. ${ }^{15}$ The BBNJ Working Group convened first in February 2006 and met periodically until it concluded its work in 2015.

The outcomes of discussions are contained in a series of reports and letters to the President of the UNGA. ${ }^{16}$ These summaries indicate the general trends in discussion and positions of delegates, either as groups or collectively, without specifying views of specific States. It is interesting to note the careful use of language even in these reports, designed to generate consensus. Thus a range of different terms is used to describe the views of delegations: 'some', 'several', 'many', 'other' and so on. Additionally, there are references to singular positions ('the view' or 'a view') and indeterminate collective positions ('delegations' or 'it'). The way in which the reports are composed tends to mask underlying ideological differences, but it definitely serves to build a sense of consensus. ${ }^{17}$ Unfortunately, it also makes it difficult to provide a detailed analysis of State positions.

Little substantive progress was made at the first meeting in 2006, which focused on the organization of work and exchanges of views on the issues forming the remit of the BBNJ. There was a general consensus that the issues were important and concern for more effective implementation of existing legal commitments. ${ }^{18}$ It was accepted that whilst the LOSC is the framework for oceans activities, other instruments are also relevant. ${ }^{19}$ Fisheries were discussed, although no firm views were expressed, other than to note the potential harm, and that other fora were relevant to dealing with them. ${ }^{20}$ Much of the subsequent BBNJ discussions are characterized by growing consensus on core issues, but divergent views remain on the institutional implications of this.

By 2008, key issues of common concern began to emerge, including capacitybuilding, the implementation of effective EIA, and the development of ABM tools. ${ }^{21}$ Consensus on these points continued to develop at the 2010 meeting, which highlighted the importance of expanding the knowledge basis for decision-making, ${ }^{22}$ the general need for cooperation and coordination in implementation, ${ }^{23}$ and capacity-

\footnotetext{
${ }^{14}$ UNGA Res. 59/24, 17 December 2004, UN Doc. A/Res/59/24, 4 February 2005.

${ }^{15}$ Ibid., at paras 73-4.

${ }^{16}$ Reports of the Ad-Hoc Open-ended Informal Working Group to study issues relating to the conservation and sustainable use of marine biological diversity beyond areas of national jurisdiction: 2006 - UN Doc. A/61/65, 20 March 2006; 2008 - UN Doc. A/63/79, 16 May 2008. Letter from the Co-Chairpersons of the Ad-Hoc Open-ended Informal Working Group to the President of the General Assembly: 2010 - UN Doc. A/65/68, 17 March 2010; 2011 - UN Doc. A/66/119, 30 June 2011; 2012 - UN Doc. 67/95, 13 June 2012; 2013 UN Doc. A/68/399, 23 Sept 2013; 2014 - UN Doc. A/68/82, 5 May 2014 and UN Doc. 69/117*, 23 July 2014; also footnote 9.

${ }^{17}$ This was manifest in the debate about whether or not MGR are part of the CHM regime. See for example UN Doc. 69/117*, para 12.

${ }^{18}$ UN Doc. A/61/65, Annex I, paras 4 and 5.

${ }^{19}$ Ibid., at para 3.

${ }^{20}$ Ibid., at para 7.

${ }^{21}$ UN Doc. A/63/79, para 54.

${ }^{22}$ UN Doc. A/65/68, paras 31-37.

${ }^{23}$ Ibid., at paras 11-12 and 42-45.
} 
building $^{24}$ There was also continued focus on ABM and EIA. ${ }^{25}$ The 2011 meeting of the BBNJ Working Group presented a series of recommendations to the UNGA. This reflected a growing consensus between groups of States on the scope of a negotiating package. ${ }^{26}$ Whilst it was generally accepted that the status quo was not an option, States were divided on the precise way forward. ${ }^{27}$ The BBNJ did not recommend an IA, but called for the initiation of a process that would address certain issues (general conservation and sustainable use of MGR in ABNJ, benefit-sharing, ABM, EIA, capacity-building and technology transfer), including through the development of an agreement under LOSC. ${ }^{28}$ UNGA Resolution 66/231 consolidated the mandate of the BBNJ Working Group in line with the above recommendations. ${ }^{29}$

In 2012, the BBNJ Working Group met shortly before the Rio+20 Summit. By this stage it appears that a number of delegations were comfortable with the notion of an implementing agreement. However, insufficient consensus remained on this point. No decision on an implementing agreement was taken at Rio+20, although States made a strong commitment at a ministerial level to address this issue as a matter of urgency, and to reach a decision on the adoption of an agreement before the end of the UNGA's $69^{\text {th }}$ session in August 2015. ${ }^{30}$ This provided much-needed political momentum. One may note that the rate of progress in BBNJ discussions improved from 2013, with the use of inter-sessional meetings, and an invitation to the Co-Chairs of the BBNJ Working Group to submit their views on the scope, parameters and feasibility of an IA under the LOSC. ${ }^{31}$ This latter point was built on in UNGA Resolution 68/70, which called upon States to submit their views on the scope, parameters, and feasibility of an IA. ${ }^{32}$ However, a lack of consensus remained on the precise scope of a negotiating package. ${ }^{33}$ Securing this was to become the main focus of the 2014 meetings. The BBNJ Group met twice (1-4 April and 16-19 June) in 2014. During the first meeting it was noted that the work of the BBNJ was reaching a critical stage, where decisions needed to be made. ${ }^{34}$ Thus discussions covered questions of form (soft law or binding agreement?), as well as potential substantive and procedural aspects of an instrument. ${ }^{35}$ Also, such matters should be addressed through an instrument falling under the LOSC. ${ }^{36}$ A preference for a binding instrument emerged. ${ }^{37}$ At the 2015 session, the recommendation to develop a legally binding instrument was taken.

On 19 June 2016, the UNGA adopted UNGA Resolution 69/292, ${ }^{38}$ which put in motion the process for formally developing an IA. It established a PrepCom open

\footnotetext{
${ }^{24}$ Ibid., at para 38 .

${ }^{25}$ Ibid., at paras 14-18.

${ }^{26}$ See S Hodgson, A Serdy, I Payne and J Gille, Towards a Possible International Agreement on Marine Biodiversity in Areas Beyond National Jurisdiction. IP/A/ENVI/2014-04 (European Parliament, 2014) p. 50.

${ }^{27}$ UN Doc. A/66/119, paras 42-3.

${ }^{28}$ Ibid., at Annex, para 1.

${ }^{29}$ UNGA Res. 66/231, paras 167-8.

${ }^{30}$ See Report of the United Nations Conference on Sustainable Development (Rio de Janeiro, Brazil 20-22 June 2012) UN Doc. A/CONF.216/16, para 162.

${ }^{31}$ UN Doc. A/68/399, Annex, para 1(d) and (e).

${ }^{32}$ UNGA Res. 68/70, para 201.

${ }^{33}$ UN Doc. A/68/399, para 50.

${ }^{34}$ UN Doc. A/68/82, para 14.

${ }^{35}$ Ibid., at paras 31-48. UN Doc 69/117*, paras 23-81.

${ }^{36}$ UN Doc. A/69/177*, para 11.

${ }^{37}$ Ibid., at paras 13-16.

${ }^{38}$ UNGA Res. 69/292, supra (n 7).
} 
to all Member States of the UN, its specialized agencies and parties to the LOSC, and it was charged with making recommendations to the UNGA on the elements of a draft text of a binding agreement. ${ }^{39}$ Although States have driven this process, both IGOs and non-governmental organizations (NGOs) provided considerable input. ${ }^{40}$

\section{PrepCom's First Meeting}

The progress made by BBNJ Working Group meant that the material scope of PrepCom's mandate is quite clear. It is to address the following issues: "the conservation and sustainable use of marine biological diversity of areas beyond national jurisdiction, in particular, together and as a whole, marine genetic resources, including questions on the sharing of benefits, measures such as area-based management tools, including marine protected areas, environmental impact assessments and capacity-building and the transfer of marine technology". ${ }^{41}$

PrepCom hosted its first meeting between 6-8 April 2016, with a second meeting scheduled between 26 August and 9 September $2016 .{ }^{42}$ The meeting was well attended, but was by no means universal, despite the aim of the UNGA to be as inclusive as possible through the participation of all States, IGOs and NGOs, not just States Parties to the LOSC. ${ }^{43}$ It was attended by 91 States Parties, 10 Non-States Parties, seven IGOs, five UN specialised agencies, five UN-funded programmes and agencies, 17 NGOs and two private commercial groups. ${ }^{44}$ Notably only one RFMO, the South East Atlantic Fisheries Organisation (SEAFO), attended, despite the importance of the ABNJ IA to fisheries. PrepCom will report to the UNGA by the end of 2017, although this does not mean a draft text will be presented at this point. Rather, an intergovernmental conference will be convened at a date to be agreed before the end of the UNGA $72^{\text {nd }}$ session (September 2017) to consider and elaborate the text of a binding agreement.

PrepCom procedures are the same as those applicable to the UNGA, with participatory rights afforded to the European Union (EU) as per the LOSC's Meetings of States Parties. ${ }^{45}$ In order to secure the widest possible agreement, PrepCom shall work, as far as possible, on the basis of consensus. ${ }^{46}$ Consensus has been facilitated through the use of informal working groups arranged on the basis of the four key aspects of the proposed agreement: Mr. Carlos Sobral Duarte (Brazil) - MGR, including benefit-sharing; Mr. John Adank (New Zealand) - ABM tools; Mr. René Lefeber (the Netherlands) - EIAs; and Ms. Rena Lee (Singapore) - capacity-building and the transfer of marine technology. It seems, however, that securing a text is the priority, as allowance is made for the draft text presented to the UNGA to contain provisions where consensus is lacking. ${ }^{47}$

${ }^{39}$ Ibid., at para $1(\mathrm{a})$.

${ }^{40} \mathrm{R}$ Warner 'Conserving marine biodiversity in areas beyond national jurisdiction: co-evolution and interaction with the law of the sea' in DR Rothwell, AG Oude Elferink, KN Scott and T Stephens (eds), The Oxford Handbook of the Law of the Sea (Oxford University Press, 2015) 52-76.

${ }^{41}$ UNGA Res. 69/292, supra (n 7), para 2.

42 There is no formal record of PrepCom discussions, other than the Chair's overview of PrepCom's first session. Available at :

http://www.un.org/depts/los/biodiversity/prepcom_files/PrepCom_1_Chair's_Overview.pdf.

However, a daily report on the discussions was published in Earth Negotiations Bulletin: http://www.iisd.ca/oceans/bbnj/prepcom1/.

${ }^{43}$ UN General Assembly Res. 69/292 (2015), para 1(a).

${ }^{44}$ Long and Chaves, supra (n 11), at 220.

${ }^{45}$ Supra (n 43), at para 1(j).

${ }^{46}$ Ibid., at para $1(\mathrm{~g})-(\mathrm{h})$.

${ }^{47}$ Supra (n 43), at para 1(i). 
The emphasis on integration at PrepCom is significant. It marks the continued faith in the success of package deal negotiations that underpinned the LOSC. More specifically, it would appear to fundamentally link questions of international fisheries regulation to the development of the IA. As discussed below, this is perhaps the most challenging issue faced by PrepCom. Indeed, the main divergence of opinion during the first meeting was the relationship between the new instrument and fisheries regulation. It is to this question we turn now.

\section{Fisheries and Governance Issues at the BBNJ Working Group and PrepCom}

\section{Fisheries and Governance Gaps}

High seas fisheries and RFMOS have been subject to a high degree of criticism, much of it noting the need for reform. ${ }^{48}$ Although fisheries regulation was not the principal object of the BBNJ Working Group's mandate, it was no surprise to see many delegations raise this issue at the first BBNJ meeting in $2006 .{ }^{49}$ In later meetings, several fisheries-specific gaps were raised by delegates, including a lack of effective flag State control over fishing vessels operating in ABNJ, the need to improve port State control, limited regulatory tools (for example, scope for market-based controls on fisheries), weak performance reviews of RFMOs, gaps in the geographical and species coverage of RFMOS, and failure to implement controls on bottom-trawl fishing. ${ }^{50}$ Whilst such issues are important, the identification of regulatory gaps in fisheries management could have been more complete, and this might have served to reinforce calls to include fisheries within a new regime. For example, the FSA does not explicitly cover discrete high seas stocks, and some gaps exist in the coverage of such stocks by RFMOs. ${ }^{51}$ The FSA provides a framework for RFMOs and other arrangements, but it does not require conformity with its provisions. ${ }^{52}$ Many but not all species are regulated by RFMOs. ${ }^{53}$ Geographic gaps in RFMO coverage include the Arctic, Central and Southwest Atlantic. ${ }^{54}$ Small vessels may be exempted from the FAO Compliance Agreement. ${ }^{55}$ More generally, institutional oversight of

\footnotetext{
${ }^{48}$ See the material cited in footnote 8. Also KM Gjerde, D Currie, K Wowk and K Sack, 'Ocean in Peril: Reforming the Management of Global Ocean Living Resources in Areas Beyond National Jurisdiction' (2013) 74(2) Marine Pollution Bulletin 540-551; A Cox, R Renwrantz and I Kelling, Strengthening Regional Fisheries Management Organizations (OECD, Paris, 2009); MW Lodge, D Anderson, T Løbach, G Munro, K Sainsbury and A Willock, Recommended Best Practices for Regional Fisheries Management Organizations (Chatham House, London, 2007); AD Rogers and M Gianni, The Implementation of UNGA Resolutions 61/105 and 64/72 in the Management of Deep-Sea Fisheries on the High Seas (International Programme on the State of the Ocean, London, 2010); S Cullis-Suzuki and D Pauly, 'Failing the High Seas: A Global Evaluation of Regional Fisheries Management Organizations' (2010) 34(5) Marine Policy 1036-1042.

${ }^{49}$ UN Doc. A/61/65, paras 9 and 23.

${ }^{50}$ See, for example, UN Doc. A/63/79, paras 40 and 42; UN Doc. A/67/95, para 30; UN Doc. A/68/82, para 47.

${ }^{51}$ Y Takei, Filling Regulatory Gaps in High Seas Fisheries. Discreet High Seas Fish Stocks, Deep-sea Fisheries and Vulnerable Marine Ecosystems (Martinus Nijhoff, Leiden, 2013) p. 4.

${ }^{52}$ See Gjerde et al, supra (n 8), at 9.

${ }^{53}$ Lodge et al, supra (n 48), xviii.

${ }^{54}$ For a general appraisal of RFMOs, see R Rayfuse, 'Regional Fisheries Management Organizations' in Rothwell et al, supra (n 40) 439-462.

55 Article II(2) of the Agreement to Promote Compliance with International Conservation and management Measures by Fishing Vessels on the High Seas 1993 (Rome, 24 November 1993, in force 24 April 2003), 2221 UNTS (No. 39486).
} 
RFMOs is lacking; no single institution is responsible for coordinating RFMO activities, or is independently mandated to review the performance of RFMOs, port States and flag States.

Delegations expressed divergent views on fisheries issues, but one point of agreement was that poorly regulated fishing was the main threat to marine biodiversity in ABNJ. At its first meeting in 2006, the BBNJ Working Group identified illegal, unregulated and unreported (IUU) fishing and destructive fishing practices as the greatest threat to ABNJ. ${ }^{56}$ Some delegations observed the existence of perverse incentives and profit from IUU fishing as one of the key drivers of harm. ${ }^{57}$ However, whilst this point was not disputed, concern with the socio-economic drivers of IUU fishing does not seem to have featured in later BBNJ Working Group discussions. In 2008, the Working Group focused on identifying anthropogenic impacts on BBNJ, and particular attention was placed on "unsustainable fishing activities, including overfishing, overcapacity, by-catch, destructive fishing practices, illegal, unreported and unregulated fishing; non-participation and non-compliance with global and regional fisheries instruments' ${ }^{58}$ Thereafter, these threats seem to have been accepted as a given, with subsequent discussions focusing on how to address knowledge gaps about the precise impacts of human activities on ABNJ. ${ }^{59}$ These discussions in turn contributed to consensus on the need for any ABNJ regime to be underpinned by sound knowledge. In this respect many delegates took the view that collection and sharing of data was critical to promoting conservation and sustainable use of marine biological diversity. ${ }^{60}$ At the 2012 meeting, it was noted that since the inception of the BBNJ process, pressures on marine resources had increased and that human activities, including overfishing, had continued to put the oceans at risk. ${ }^{61}$ In 2014, it was noted that "unsustainable fishing, in particular overfishing, illegal, unreported and unregulated fishing and certain destructive fishing practices, was the greatest threat to marine biodiversity in those areas". ${ }^{62}$ This presented States with something of a dilemma because if the subject-matter of an ABNJ agreement excluded fisheries, then how could it establish a workable regime for the conservation and sustainable use of ABNJ?

In general, delegations were of the view that implementation could be enhanced by securing universal participation in the LOSC and other agreements. ${ }^{63}$ This point is worth stressing, because the adoption of an ABNJ IA will not resolve the gaps in RFMO coverage. This is something that depends upon the political will of States, as well as suitable socio-economic conditions. This latter point may require some degree of support for developing States. Already obligations of support, by way of capacity-building measures, exist under the FSA. ${ }^{64}$ However, this would not necessarily result in all gaps being closed, particularly those that cut across different sectors. To this end several delegations also raised the issue of how existing institutions could develop and adopt initiatives, guidelines and regulations within existing mandates. ${ }^{65}$

\footnotetext{
${ }^{56}$ Ibid., at para 33, and Annex I, paras 7-8.

${ }^{57}$ Ibid., at para 37.

${ }^{58}$ UN Doc. A/63/79, para 13.

${ }^{59}$ See for example: UN Doc. A/61/65, paras 19, 45 and 45; UN Doc. A/68/399, para 33.

${ }^{60}$ UN Doc. A/65/68, para 34; UN Doc. A/68/399, para 33.

${ }^{61}$ UN Doc. A/67/95, para 14.

${ }^{62}$ UN Doc. A/68/82, para 10. Also UN Doc. 69/117*, para 8.

${ }^{63}$ UN Doc. A/65/68, para 43.

${ }^{64}$ See FSA, supra (n 5), Art. 25

${ }^{65}$ UN Doc. A/67/95, para 40.
} 
Unfortunately, the question of how to address governance gaps in fisheries provoked quite polarized views during the BBNJ discussions. Some delegations took the view that a lack of political will to implement existing instruments would not be resolved by a new international instrument. ${ }^{66}$ Some delegations adopted the position that the FSA and other fisheries instruments and RFMOs were the appropriate means for dealing with fisheries matters. ${ }^{67}$ Others doubted that RFMOs had the capability or competence to deal with all fisheries issues in ABNJ because they lacked a holistic approach/capacity, had either a single-species mandate, or lacked mechanisms for dealing with non-fisheries issues such as vulnerable ecosystems. ${ }^{68}$ Given the noted existence of regulatory gaps, as opposed to implementation issues, other delegations appeared to support the inclusion of fisheries within subsequent measures for ABNJ. ${ }^{69}$ Some delegations observed that there was a need for new RFMOs to close geographic gaps and for existing RFMOs to have their mandate strengthened. ${ }^{70}$ Amidst these uncertainties and divergence of opinions, one thing did seem clear: a lack of will to expand the competence of RFMOs beyond fisheries matters. ${ }^{71}$ More generally, the Co-Chairs' Report and Summary specifically raised the importance of identifying gaps, with the aim of securing an effective legal framework. ${ }^{72}$ This was not limited to 'legal' gaps, but included issues of participation and implementation. ${ }^{73}$ This left matters open on how best to progress, including on key issues related to fisheries.

During PrepCom, the tension between delegations favoring either the inclusion or exclusion of fisheries re-emerged. Indeed, this was probably the dominant feature of discussions. On the one hand, Iceland, Japan, and the Russian Federation were quite robust in their view that fisheries were not to be included within an international legally binding instrument on ABNJ. ${ }^{74}$ On the other hand, a larger number of delegations or groups (the African Group, Costa Rica, Indonesia, Jamaica, New Zealand, Norway, Peru, and the USA) issued statements favoring the inclusion of fisheries. ${ }^{75}$ This appears to indicate a change in position by some States from that adopted at the BBNJ Working Group who were originally equivocal about the inclusion of fisheries. Whether or not this trend continues will become clearer at subsequent meetings. The IUCN favored inclusion, and this seems implicit in the views of Greenpeace, the High Seas Alliance, the Natural Resources Defense Council and Pew, who advocated a comprehensive binding instrument. ${ }^{76}$ It is likely that RFMOs will have more prominence at the August/September 2016 meeting, and with greater clarity on the position of RFMOs, it is expected that more States will clarify their position on the inclusion of fisheries in the ABNJ IA.

Given that States appear to have accepted that the proposed ABNJ IA should address governance gaps, there appear to be two realistic options for going forward. The first is to consider collaborative institutional mechanisms to integrate fisheries with other environmental and resource-related activities. The second is to advance a

\footnotetext{
${ }^{66}$ UN Doc. A/68/82, paras 47 and 73.

${ }^{67}$ UN Doc. A/61/65, para 24; UN Doc. A/65/68, para 44.

${ }^{68}$ UN Doc. A/61/65, para 25.

${ }^{69}$ UN Doc. A/69/82, para 47.

${ }^{70}$ UN Doc. A/66/119, para 55.

${ }^{71}$ UN Doc. A/63/79, para 24.

72 UN Doc A/67/95, Annex, paras 29-47.

${ }^{73}$ Ibid., at para 31

${ }^{74}$ Earth Negotiations Bulletin, (2016) vol. 25/97, pp. 1-2 and Earth Negotiations Bulletin, (2016) vol. 25/98, p. 2.

${ }^{75}$ Ibid.

${ }^{76} \mathrm{Ibid}$.
} 
set of cross-cutting governance principles that can promote substantive integration by shaping the conduct of States, RFMOs and other institutions with mandates in ABNJ. It is possible that either approach or some combination of the two could be accommodated within the proposed ABNJ IA. These positions are considered in turn.

\section{Integrated Approaches to the Conservation and Sustainable Use of Marine Biological Diversity}

The need for greater integration between different sectoral activities is generally recognized, but remains a significant challenge in a decentralized legal system. ${ }^{77}$ From the outset, delegations to the BBNJ Working Group attached importance to enhanced cooperation in respect of ABNJ via existing mechanisms, including through RFMOs, and between RFMOs and regional arrangements for the protection of the marine environment. ${ }^{78}$ This was reiterated in the recommendations of the BBNJ to the UNGA in 2010, which called upon States and competent international organizations to cooperate as appropriate through regional seas conventions and RFMOs. ${ }^{79}$ The importance of integration was highlighted by some delegations in $2011^{80}$ and $2012 .{ }^{81}$ It is notable that some delegations called for a coordinated crosssectoral approach which would take into account the cumulative impact of human activities in ABNJ. ${ }^{82}$ It is precisely this potential for cumulative impacts from different sectoral activities that provides a strong justification for integrated management, and is discussed further below.

Once the idea of a legally binding instrument started to gain traction at the BBNJ meetings, discussions tended to focus on the relationship between a new agreement and existing fisheries agreements. This manifested itself in discussions about 'complementarity' - the idea that existing mandates are not infringed, nor existing efforts duplicated. ${ }^{83}$ However, beyond this, the records reveal little about how this idea could be accomplished. It is suggested that this could be achieved through the inclusion of a carefully drafted 'conflicts clause' in an IA. ${ }^{84}$ Alternatively it could be secured through a treaty provision that requires compatibility of approaches, similar to Article 4 of the FSA. ${ }^{85}$ Ideally both provisions should be utilized because this would help drive collaboration and sharing of practices across different institutions and sectors. One delegation did suggest that an IA should be limited to areas that were not covered by existing institutions. ${ }^{86}$ However, it was not clear whether this referred to geographic areas or substantive issues or both. Regardless of which approach was intended, such an ad hoc approach to gap-filling

\footnotetext{
${ }^{77}$ See R Rayfuse and R Warner, 'Securing a Sustainable Future for the Oceans beyond National Jurisdiction: The Legal Basis for an Integrated Cross Sectoral Regime for High Seas Governance for the $21^{\text {st }}$ Century' (2008) 23(3) IJMCL 399-421, at 413; K Scott, 'Integrated Oceans Management. A New Frontier in Marine Environmental Protection' in Rothwell et al, supra (n 40), 463-490; J Harrison, 'The Law of the Sea Convention Institutions', in Rothwell et al, supra (n 40), 373-394.

${ }^{78}$ UN Doc. A/63/79, para 24.

${ }^{79}$ UN Doc. A/65/68, para 12.

${ }^{80}$ UN Doc. A/66/119, para 14

${ }^{81}$ UN Doc. A/67/95, para 13.

${ }^{82}$ UN Doc. A/66/119, para 14.

${ }^{83}$ UN Doc. A/67/95, para 29; UN Doc. A/68/82, para 41. Also, UNGA Res. 69/292 (n 10).

${ }^{84}$ See Art. 311 of the LOSC. This is governed under Article 30 of the Vienna Convention on the Law of Treaties 1969 (Vienna, 23 May 1969, in force 27 January 1980), 1155 UNTS 331. See further O Corten and P Klein (eds), The Vienna Conventions on the Law of Treaties. A Commentary (Oxford University Press, Oxford, 2011), vol. 1, p. 764.

${ }^{85}$ See UN Doc. 69/117*, para 31.

${ }^{86}$ UN Doc. 69/117*, para 19.
} 
should be avoided because it would result in unnecessary complexity and fragmentation.

As noted above, an integrated approach was part of PrepCom's mandate. ${ }^{87}$ All participants supported this, either explicitly through the language of cooperation, or through calls to respect existing institutions and mandates. During the discussions, the general principle of integration quickly manifested itself in specific contexts, such as calls for cumulative EIA and inclusive approaches to ABM. For example, the African Group noted that an integrated approach to the creation of marine protected areas (MPAs) cannot be advanced through RFMOs, presumably due to their limited mandates. ${ }^{88}$ Jamaica called for a binding instrument to adopt an integrated approach inclusive of fisheries. ${ }^{89}$ Given the prevailing consensus for cross-cutting integrated approaches, something that cannot be ignored if the ABNJ incorporates provisions on $\mathrm{ABM}$ and EIA, the question is how best to secure this.

Arguably, several options for integration exist. ${ }^{90}$ The archetypes are mapped out in Figure 1.

\section{Strong Integration}

\begin{tabular}{|c|c|}
\hline $\begin{array}{l}\text { A1 Single ABNJ Management } \\
\text { Authority } \\
\text { - ISA+ option } \\
\text { - Single multi-sector institution } \\
\text { with comprehensive } \\
\text { planning/licensing authority, } \\
\text { established under a binding } \\
\text { instrument. }\end{array}$ & $\begin{array}{l}\text { B1 Composite Regional ABNJ } \\
\text { Management Organizations } \\
\text { - Combined RFMO/regional } \\
\text { environmental management } \\
\text { regimes } \\
\text { - Revised mandates and } \\
\text { institutional arrangements } \\
\text { governed under a strong binding } \\
\text { agreement. }\end{array}$ \\
\hline $\begin{array}{l}\text { A2 ABNJ Advisory Body/Process } \\
\text { - Status quo } \\
\text { - Non-binding guidelines } \\
\text { advanced through resolutions of } \\
\text { the UNGA. }\end{array}$ & $\begin{array}{l}\text { B2 Coordinated Sectoral } \\
\text { Management Organizations } \\
\text { - 'Enhanced status quo'. } \\
\text { - Retain regional bodies, subject to } \\
\text { structured coordination and } \\
\text { revised obligations set out in a } \\
\text { framework instrument. }\end{array}$ \\
\hline
\end{tabular}

\section{Weak Integration}

Figure 1: Scenarios and characteristics of institutional arrangements for ABNJ

A1 - This would involve the creation of a new supra-national institution responsible for the management of all activities in ABNJ, including deep seabed mining, deep and high seas fisheries, marine scientific research, tourism, and environmental protection. It may be likened to an International Seabed Authority (ISA) + option, with defined institutional structures, governance principles, and decision-making authority and

\footnotetext{
${ }^{87}$ UNGA Res. 69/292 Supra (n7).

${ }^{88}$ Earth Negotiations Bulletin, (2016) vol. 25/102, p. 1.

${ }^{89}$ Earth Negotiations Bulletin, (2016) vol. 25/98, p. 2.

${ }^{90}$ See also: IUCN, An International Instrument on Conservation and Sustainable Use of Biodiversity in Marine Areas Beyond National Jurisdiction. Matrix of Suggestions (IUCN, Gland, 2016), section 6. Available at http://cmsdata.iucn.org/downloads/iucn_bbnj_matrix_december_2015.pdf
} 
associated compliance mechanisms. Through such processes the body (as opposed to individual States, or regional arrangements) would be responsible for adopting a management plan for $\mathrm{ABNJ}$, identifying specific regulatory options and securing their implementation.

A2 - This perhaps reflects the status quo. Different sectoral bodies retain their discrete functions and consider ABNJ only peripherally. Centralized consideration of ABNJ is left to informal UN processes centered on the UNGA, which continues to issue or commission guidelines on specific activities. These guidelines may be followed by States or other institutions at their discretion.

B1 - Fully integrated regional marine management organizations are established to regulate deep seabed mining, deep and high seas fisheries, marine scientific research, tourism, environmental protection. These could be based on the existing regional arrangements for different ocean areas (e.g., NE Atlantic, NW Atlantic and so on), with their geographic mandate extended and coordinated to cover all ABNJ. They would be authorized to use a system of marine spatial planning and associated tools to regulate all activities within the region.

B2 - Existing bodies retain their sectoral mandates, but extend their sectoral remits to ABNJ to ensure gaps are filled. They are mandated/encouraged to coordinate their sectoral activities through ad-hoc interactions based upon a set of governance principles and specific management tools.

The discussions at the BBNJ and PrepCom are at too early a stage to reveal States' clear preferences for one or the other approach. However, delegations were alert to the consequences of both approaches, and it is possible to gauge the direction of change from reports of the BBNJ Working Group and PrepCom. As noted above, a strong/holistic approach has significant implications for the structure and functioning of existing sectoral arrangements for fisheries. This also holds true for pollution control regimes, such as MARPOL and regional seas arrangements. This approach would require profound institutional reform - something that States appear to be set against. A decentralised approach is more realistic, and it would ensure that existing approaches are preserved. However, it leaves many questions unanswered about how fisheries should be integrated within any future regime. Integration could be secured through procedures to ensure that relevant interests, concerns, standards and approaches are taken into account within different agencies. Already this is occurring outside of the UN processes. A good example is the Memorandum of Understanding (MOU) between the NE Atlantic Fisheries Commission (NEAFC) and the OSPAR Commission adopted in September 2008, which recognizes respective competences and areas of shared concern, and establishes processes for sharing of information, joint discussions and common approaches to the application of precautionary approaches and ABM. ${ }^{91}$ There is little reason why such an approach to information-sharing and advisory input could not form part of other joint initiatives between different sectoral institutions. ${ }^{92}$ This approach has the advantage of organic,

\footnotetext{
${ }^{91}$ A similar agreement was agreed between OSPAR and other institutions: the International Seabed Authority (2011) and the North Atlantic Salmon Conservation Organization (2013). A collaborative arrangement was also adopted between OSPAR and the Sargasso Sea Alliance in 2012. These are available at http://www.ospar.org/about/international-cooperation/memoranda-of-understanding. ${ }^{92}$ UN Doc. A/65/68, para 34.
} 
adaptive development and could generate stronger traction than a heavy-handed, topdown approach. To an extent, the proposed implementation regime is a default regime - one designed to tackle matters left unresolved by other instruments. As such the pathway is already set against more radical reform of ABNJ governance. Taking a purely fisheries perspective, it should be recalled that existing fisheries arrangements are not only concerned with the conduct of fisheries activities, but also about entitlement to obtain access to resources. It is critical that States within RFMOs and regional arrangements have relatively stable access to and control over fisheries, and they are unlikely to risk compromising such entitlements. Whilst States may be willing to accept wider governance responsibilities for fisheries in ABNJ, it is difficult to imagine that they would explode existing access arrangements to do this.

\section{Governance Principles for ABNJ and Fisheries}

The second approach to addressing governance gaps is to advance a holistic set of governance principles for ABNJ. Already some fruitful discussion of such principles has occurred, ${ }^{93}$ and during the BBNJ discussions, a high degree of consensus on such principles appeared to prevail. ${ }^{94}$ The report of the 2014 BBNJ meeting compiled a list of these principles, including: balance between competing uses of the oceans and between conservation and sustainable use; protection and preservation of the marine environment, equitable utilization; cooperation; precautionary approach; decisionmaking based on best available science; ecosystem approach; integrated approach; adaptive management; public participation in decision-making processes; involvement of regional and sectoral stakeholders; open and transparent processes; public availability of information; CHM; freedom of the high seas; common but differentiated responsibilities; special requirements of developing countries, including landlocked States; duty not to transfer damage or hazards or transform one type of pollution into another; polluter-pays principle; cumulative impacts; flexibility and ability to address cumulative pressures; solidarity; and flag State jurisdiction as a basis for enforcement on the high seas. This list comprises a mix of established legal principles (e.g., precautionary principle) and other ideas, approaches, rules and attributes (e.g., solidarity, cumulative impacts and adaptive management). It is also clear that there is potential overlap/repetition of principles, so some degree of rationalization will be necessary as the discussions advance.

It is quite likely that some of these principles/approaches will form a substantive part of the proposed instrument, perhaps in a manner similar to Article 5 of the FSA. This is important because this will likely require existing RFMOs with an ABNJ mandate to respect such principles when adopting conservation and management measures. It may even require amendment of constituent instruments where existing mandates are too restrictive or ambiguous. To help indicate the extent to which such principles will affect existing RFMOs, Table 1 below shows the extent to which a number of key principles are found within the constituent instruments of Regional Fisheries Bodies (RFBs) and the FSA. ${ }^{95}$

\footnotetext{
${ }^{93}$ See the Chair's summary, supra (n 42). More generally, see the articles by D Freestone, AG Oude Elferink and RA Barnes in the special issue of (2012) 27(2) IJMCL.

${ }^{94}$ See the Informal Co-Chairs' overview of issues raised during the first round of discussions on the scope, parameters and feasibility of an international instrument under the LOSC. Appendix, UN Doc. A/69/82, 4 May 2014.

${ }^{95}$ RFBs includes both advisory bodies and those competent to adopt binding conservation and management measures. The table includes: Asia-Pacific Fisheries Commission (APFIC), Commission
} 


\begin{tabular}{|c|c|c|c|c|c|c|c|c|c|c|c|}
\hline & 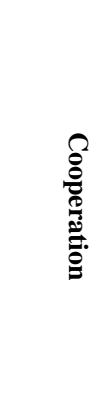 & 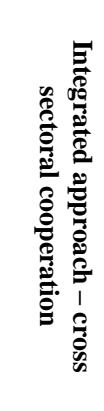 & 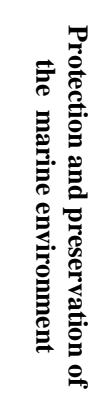 & 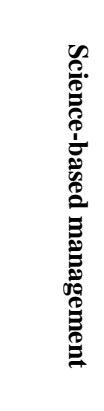 & 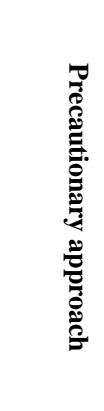 & 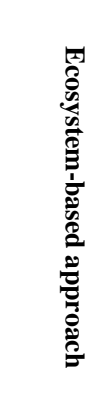 & 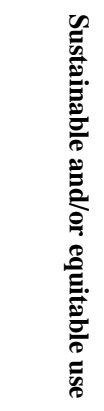 & 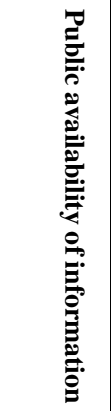 & 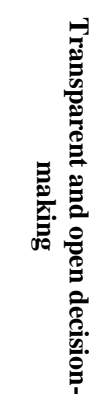 & 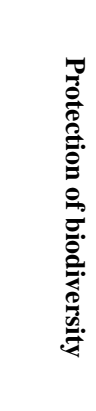 & 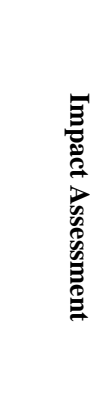 \\
\hline $\begin{array}{l}\text { FSA } \\
1995\end{array}$ & $\begin{array}{l}\text { Art. } \\
5\end{array}$ & $\begin{array}{l}\text { Art } \\
24 .\end{array}$ & $\begin{array}{l}\text { Art. } \\
6\end{array}$ & $\begin{array}{l}\text { Art } \\
5(b)\end{array}$ & $\begin{array}{l}\text { Art. } \\
6\end{array}$ & $\begin{array}{l}\text { Art. } \\
5(\mathrm{e})\end{array}$ & $\begin{array}{l}\text { Arts. } \\
5(a) \\
\text { and } \\
24\end{array}$ & $\begin{array}{l}\text { Art. } \\
14(3)\end{array}$ & $\begin{array}{l}\text { Art. } \\
12\end{array}$ & $\begin{array}{l}\text { Art. } \\
5(\mathrm{~g})\end{array}$ & $\begin{array}{l}\text { Art. } \\
5(d)\end{array}$ \\
\hline $\begin{array}{l}\text { APFI } \\
\text { C }\end{array}$ & $\begin{array}{l}\text { Art. } \\
\text { VII }\end{array}$ & & $\begin{array}{l}\text { Art } \\
\text { IV } \\
\text { (b)(3 } \\
\text { ) }\end{array}$ & & & & $\begin{array}{l}\text { Art } \\
\text { IV(b } \\
\text { )(i) }\end{array}$ & $\begin{array}{l}\text { Art } \\
\text { IV( } \\
\text { G) }\end{array}$ & & & \\
\hline $\begin{array}{l}\text { CCA } \\
\text { MLR }\end{array}$ & $\begin{array}{l}\text { Pre- } \\
\text { ambl } \\
\text { e }\end{array}$ & $\begin{array}{l}\text { Arts } \\
\text { III } \\
\text { and } \\
\text { V }\end{array}$ & $\begin{array}{l}\text { Arts } \\
\text { II } \\
\text { and } \\
\text { VI }\end{array}$ & $\begin{array}{l}\text { Art } \\
\text { IX(1 } \\
)(f)\end{array}$ & $\begin{array}{l}\text { Art } \\
\text { Ii(3) } \\
\text { (c) }\end{array}$ & $\begin{array}{l}\text { Art } \\
\text { Ii(3) } \\
\text { (c) }\end{array}$ & $\begin{array}{l}\text { Art } \\
\text { Ii(3) } \\
\text { (c) }\end{array}$ & $\begin{array}{l}\text { Art } \\
\text { IX(1 } \\
)(d)\end{array}$ & & & $\begin{array}{l}\text { Art. } \\
X X( \\
4)\end{array}$ \\
\hline $\begin{array}{l}\text { CCS } \\
\text { BT }\end{array}$ & $\begin{array}{l}\text { Pre- } \\
\text { ambl } \\
\text { e }\end{array}$ & & & $\begin{array}{l}\text { Arts } \\
5 \\
\text { and } \\
8\end{array}$ & & & $\begin{array}{l}\text { Art. } \\
8(4)\end{array}$ & & & & \\
\hline $\begin{array}{l}\text { CEC } \\
\text { AF }\end{array}$ & $\begin{array}{l}\text { Art. } \\
3\end{array}$ & & $\begin{array}{l}\text { revis } \\
\text { ed } \\
\text { statu } \\
\text { te }\end{array}$ & & & & & $\begin{array}{r}\text { Art } \\
\text { 3(d) }\end{array}$ & & & \\
\hline $\begin{array}{l}\text { GFC } \\
\text { M }\end{array}$ & $\begin{array}{l}\text { Pre- } \\
\text { ambl } \\
\text { e }\end{array}$ & & $\begin{array}{l}\text { Art } \\
5(d)\end{array}$ & $\begin{array}{l}\text { Art. } \\
5(b)\end{array}$ & $\begin{array}{l}\text { Art. } \\
5(\mathrm{c})\end{array}$ & $\begin{array}{l}\text { Art. } \\
\text { 8(b) }\end{array}$ & $\begin{array}{l}\text { Art. } \\
2(2)\end{array}$ & $\begin{array}{l}\text { Art } \\
8(b)\end{array}$ & & & \\
\hline $\begin{array}{l}\text { IATT } \\
\text { C }\end{array}$ & $\begin{array}{l}\text { Pre- } \\
\text { ambl } \\
\text { e }\end{array}$ & $\begin{array}{l}\text { Art. } \\
\text { XVI } \\
(2)\end{array}$ & $\begin{array}{l}\text { Arts. } \\
\text { VII( } \\
1) \\
\text { (k) } \\
\text { and } \\
\text { XV( }\end{array}$ & $\begin{array}{l}\text { Art. } \\
\text { VII } \\
(1)(\mathrm{c} \\
)\end{array}$ & $\begin{array}{l}\text { Art. } \\
\text { IV }\end{array}$ & $\begin{array}{l}\text { Art. } \\
\text { VII } \\
\text { (1)(f } \\
\text { ) }\end{array}$ & $\begin{array}{l}\text { Art. } \\
\text { II }\end{array}$ & $\begin{array}{l}\text { Arts } \\
\text { XII } \\
(2)(j \\
) \\
\text { and } \\
\text { XVI }\end{array}$ & $\begin{array}{l}\text { Art. } \\
\text { XVI }\end{array}$ & & \\
\hline
\end{tabular}

for the Conservation of Antarctic Marine Living Resources (CCAMLR), Commission for the Conservation of Southern Bluefin Tuna (CCSBT), Fishery Committee for the Eastern Central Atlantic (CECAF), General Fisheries Commission for the Mediterranean (GFCM), Inter-American Tropical Tuna Commission (IATTC), International Commission for the Conservation of Atlantic Tunas (ICCAT), Indian Ocean Tuna Commission (IOTC), Northwest Atlantic Fisheries Organization (NAFO), North-East Atlantic Fisheries Commission (NEAFC), North Pacific Anadromous Fish Commission (NPAFC), North Pacific Fisheries Commission (NPFC), South East Atlantic Fisheries Organisation (SEAFO), South Indian Ocean Fisheries Agreement (SIOFA), South Pacific Regional Fisheries Management Organisation (SPRFMO), West and Central Pacific Fisheries Commission (WCPFC) and Western and Central Atlantic Fishery Commission (WECAF). 


\begin{tabular}{|c|c|c|c|c|c|c|c|c|c|c|c|}
\hline & & & 3) & & & & & $\begin{array}{l}(1) \\
\text { (a) }\end{array}$ & & & \\
\hline $\begin{array}{l}\text { ICCA } \\
T\end{array}$ & $\begin{array}{l}\text { Pre- } \\
\text { ambl } \\
\text { e }\end{array}$ & & & $\begin{array}{l}\text { Art. } \\
\text { IV }\end{array}$ & & & $\begin{array}{l}\text { Art. } \\
\text { IV } \\
(2)(b \\
\text { ) }\end{array}$ & $\begin{array}{l}\text { Art. } \\
\text { IV } \\
(2)(d \\
\text { ) }\end{array}$ & & & \\
\hline IOTC & $\begin{array}{l}\text { Art. } \\
\operatorname{IV}(3 \\
)\end{array}$ & & & $\begin{array}{l}\text { Art. } \\
V(2)\end{array}$ & & & $\begin{array}{l}\text { Art. } \\
\text { V(1) }\end{array}$ & $\begin{array}{l}\text { Art. } \\
\mathrm{V}(2) \\
\text { (a) }\end{array}$ & & & $\begin{array}{l}\text { Art. } \\
\text { XII } \\
(4)(b \\
)\end{array}$ \\
\hline $\begin{array}{l}\text { NAF } \\
\text { O }\end{array}$ & $\begin{array}{l}\text { Art. } \\
\text { II }\end{array}$ & & & $\begin{array}{l}\text { Arts } \\
\text { II } \\
\text { and } \\
\text { VI }\end{array}$ & & $\begin{array}{l}\text { Art. } \\
\text { VI }\end{array}$ & & $\begin{array}{l}\text { Art. } \\
\text { IV(1 } \\
\text { ) (b) }\end{array}$ & & & \\
\hline $\begin{array}{l}\text { NEA } \\
\text { FC }\end{array}$ & $\begin{array}{l}\text { Pre- } \\
\text { ambl } \\
\text { e }\end{array}$ & & $\begin{array}{l}\text { Art. } \\
2\end{array}$ & $\begin{array}{l}\text { Art. } \\
4 \mid(2) \\
\text { (a) }\end{array}$ & $\begin{array}{l}\text { Art. } \\
4(2)( \\
\text { b) }\end{array}$ & $\begin{array}{l}\text { Art. } \\
4(2)( \\
\text { c) }\end{array}$ & $\begin{array}{l}\text { Art. } \\
2\end{array}$ & $\begin{array}{l}\text { Art. } \\
11(2 \\
)\end{array}$ & & $\begin{array}{l}\text { Art. } \\
4(2)( \\
\text { d) }\end{array}$ & $\begin{array}{l}\text { Art. } \\
4(2)( \\
\text { c) }\end{array}$ \\
\hline $\begin{array}{l}\text { NPA } \\
\text { FC }\end{array}$ & $\begin{array}{l}\text { Art. } \\
\text { IV(4 } \\
)\end{array}$ & & & $\begin{array}{l}\text { Art. } \\
\text { VII }\end{array}$ & & & & $\begin{array}{l}\text { Art. } \\
X(2)\end{array}$ & & & \\
\hline $\begin{array}{l}\text { NPF } \\
\mathrm{C}\end{array}$ & $\begin{array}{l}\text { Art. } \\
7(2)( \\
\text { d) }\end{array}$ & $\begin{array}{l}\text { Pre- } \\
\text { ambl } \\
\text { e }\end{array}$ & $\begin{array}{l}\text { Art. } \\
3(\mathrm{k})\end{array}$ & $\begin{array}{l}\text { Art. } \\
\text { 3(b) }\end{array}$ & $\begin{array}{l}\text { Art. } \\
3(\mathrm{c})\end{array}$ & $\begin{array}{l}\text { Art } \\
\text { 3(d) }\end{array}$ & $\begin{array}{l}\text { Art. } \\
\text { 3(a) }\end{array}$ & $\begin{array}{l}? \\
\text { Art. } \\
16 \\
\text { and1 } \\
8\end{array}$ & $\begin{array}{l}\text { Art. } \\
18\end{array}$ & $\begin{array}{l}\text { Art. } \\
\text { 3(e) }\end{array}$ & $\begin{array}{l}\text { Art. } \\
3(\mathrm{~h})\end{array}$ \\
\hline $\begin{array}{l}\text { SEAF } \\
\text { O }\end{array}$ & $\begin{array}{l}\text { Pre- } \\
\text { ambl } \\
\text { e }\end{array}$ & & $\begin{array}{l}\text { Art. } \\
7\end{array}$ & $\begin{array}{l}\text { Art. } \\
\text { 3(a) }\end{array}$ & $\begin{array}{l}\text { Art. } \\
7\end{array}$ & $\begin{array}{l}\text { Art. } \\
\text { 3(d) }\end{array}$ & $\begin{array}{l}\text { Art. } \\
2\end{array}$ & $\begin{array}{l}\text { Art } \\
6(3)\end{array}$ & $\begin{array}{l}\text { Art } \\
8(9)\end{array}$ & $\begin{array}{l}\text { Art. } \\
\text { 3(f) }\end{array}$ & $\begin{array}{l}\text { Art } \\
3(\mathrm{c})\end{array}$ \\
\hline $\begin{array}{l}\text { SIOF } \\
\text { A }\end{array}$ & $\begin{array}{l}\text { Art. } \\
2\end{array}$ & $\begin{array}{l}\text { Art } \\
16\end{array}$ & $\begin{array}{l}\text { Art. } \\
4(\mathrm{e})\end{array}$ & $\begin{array}{l}\text { Art. } \\
\text { 4(a) }\end{array}$ & $\begin{array}{l}\text { Art. } \\
\text { 4(c) }\end{array}$ & $\begin{array}{l}\text { Art. } \\
4(a)\end{array}$ & $\begin{array}{l}\text { Art. } \\
2\end{array}$ & $\begin{array}{l}\text { Art. } \\
14\end{array}$ & $\begin{array}{l}\text { Art. } \\
14\end{array}$ & $\begin{array}{l}\text { Art. } \\
4(f)\end{array}$ & $\begin{array}{l}\text { Art. } \\
7(1)( \\
\text { a)(i) }\end{array}$ \\
\hline $\begin{array}{l}\text { SPRF } \\
\text { MO }\end{array}$ & $\begin{array}{l}\text { Art. } \\
3 \\
(1)(a \\
\text { ) } \\
\text { (vi) }\end{array}$ & $\begin{array}{l}\text { Art. } \\
31\end{array}$ & $\begin{array}{l}\text { Art. } \\
3(1)( \\
\text { a)(ii) }\end{array}$ & $\begin{array}{l}\text { Art. } \\
3(1)( \\
\text { a)(v) }\end{array}$ & $\begin{array}{l}\text { Art. } \\
3(2)\end{array}$ & $\begin{array}{l}\text { Art. } \\
3(2)\end{array}$ & $\begin{array}{l}\text { Art. } \\
2\end{array}$ & $\begin{array}{l}\text { Arts. } \\
10(3 \\
), \\
18\end{array}$ & $\begin{array}{l}\text { Art. } \\
18\end{array}$ & $\begin{array}{l}\text { Pre- } \\
\text { ambl } \\
\text { e }\end{array}$ & $\begin{array}{l}\text { Art. } \\
10\end{array}$ \\
\hline $\begin{array}{l}\text { WCP } \\
\text { FC }\end{array}$ & $\begin{array}{l}\text { Art. } \\
5\end{array}$ & $\begin{array}{l}\text { Art. } \\
22\end{array}$ & & $\begin{array}{l}\text { Art. } \\
5(b)\end{array}$ & $\begin{array}{l}\text { Art. } \\
6\end{array}$ & & $\begin{array}{l}\text { Art. } \\
5(a)\end{array}$ & $\begin{array}{l}\text { Arts. } \\
10 \\
(1) \\
\text { and } \\
13(3 \\
)\end{array}$ & $\begin{array}{l}\text { Art. } \\
21\end{array}$ & $\begin{array}{l}\text { Art. } \\
5(\mathrm{f})\end{array}$ & $\begin{array}{l}\text { Art. } \\
5(\mathrm{~d})\end{array}$ \\
\hline $\begin{array}{l}\text { WEC } \\
\text { AFC }\end{array}$ & & $\begin{array}{l}\text { Arts } \\
2(c) \\
\text { and } \\
11\end{array}$ & & $\begin{array}{l}\text { Art. } \\
6(\mathrm{~g})\end{array}$ & $\begin{array}{l}\text { Art. } \\
2 \text { (a) }\end{array}$ & $\begin{array}{l}\text { Art. } \\
\text { 2(a) }\end{array}$ & & $\begin{array}{l}\text { Art } \\
6(f)\end{array}$ & & & \\
\hline
\end{tabular}

Table 1. Matrix of ABNJ Governance Principles in Regional Fisheries Bodies

As the table indicates, the main gaps are in respect of cross-sectoral integration, transparent decision-making, and obligation to protect and preserve the marine 
environment and biodiversity. Such gaps tend to arise in respect of RFMOs established before the FSA in 1995. The table only encompasses the constituent agreements of the various bodies, and some RFMOs have advanced these principles/approaches through management decisions. For example, ICCAT adopted a precautionary approach to the implementation of conservation and management measures in $2015,{ }^{96}$ and NAFO adopted a precautionary approach framework in 2004. ${ }^{97}$ However, this falls someway short of a systematic approach to the governance of ABNJ.

A more detailed analysis of these provisions reveals qualitative variations in the way core principles are used in RFBs. Some instruments refer to integrated approaches, but this is generally quite weak and limited to exhortations to cooperate with other interested organizations. ${ }^{98}$ Even within the FSA, such cross-sectoral cooperation seems to be limited to provisions on developing States. ${ }^{99}$ In contrast, as noted above, OSPAR has developed links with NEFAC. Also, a MOU has been adopted between WCPFC and the Secretariat of the Pacific Regional Environmental Forum. ${ }^{100}$ It goes beyond the scope of this paper to analyze this in detail, but it may be noted that the relationships are complex, and often undermined by lack of experience and institutional capacity on both sides. ${ }^{101}$

For example, APFIC refers to prevention of pollution, but only insofar as it affects resources, and this falls some way short of a general commitment to protection of the environment. ${ }^{102}$ In contrast, NAFO is quite detailed in referring to the actual environmental impacts of fishing. ${ }^{103}$ In some it is difficult to determine whether an approach or principle is included. For example, in the WCPFC an ecosystem-based approach might be implicit from the Preamble and Articles 5(d), 12(2)(c), and 13(3), but it is not mentioned directly. ${ }^{104}$ All RFBs refer to the use of science and data, but some do not refer to the use of best available science. ${ }^{105}$ Although most instruments refer to some form of stock assessment process, this falls some way short of best practices used in EIAs, and often does not consider the impact of fishing on the wider

\footnotetext{
${ }^{96}$ ICCAT Resolution 15/12 Concerning the Use of a Precautionary Approach in Implementing ICCAT Conservation and Management Measures. https://www.iccat.int/Documents/Recs/compendiopdfe/2015-12-e.pdf.

${ }^{97}$ NAFO/FC Doc. 04/18. Available at http://archive.nafo.int/open/fc/2004/fcdoc04-18.pdf

${ }^{98}$ See for example, WECAFC, SPRFMO and SIOFA. CCAMLR is perhaps strongest in this respect, given that it is linked to the broader Antarctic treaty system.

${ }^{99}$ FSA, supra (n 5), Art. 24.

100 WCPFC Cooperates with the SPREP via a MOU: https://www.wcpfc.int/system/files/WCPFCSPREP\%20Memorandum\%20of\%20Understanding.pdf.

${ }^{101}$ See generally, UNEP, Regional Oceans Governance Making Regional Seas Programmes, Regional Fishery Bodies and Large Marine Ecosystem Mechanisms Work Better Together (UNEP, Nairobi, 2016).

102 Agreement for the Establishment of the Asia-Pacific Fishery Commission 19486 (Baguio, formulated 26 February 1948, Approved Washington 15-29 November 1948, in force 9 November 1948), 1615 UNTS 59), as amended 1996, Art. IV(b)(3). Most recent version available at http://www.fao.org/apfic/background/apfic-agreement/en/

${ }^{103}$ See Convention on Future Multilateral Cooperation in the Northwest Atlantic Fisheries 1978 (Ottawa, adopted, 24 October 1978, in force 1 January 1979), as amended in 2007, Art. III(i). Most recent text available at http://www.nafo.int/about/frames/convention.html

${ }^{104}$ Convention for the Conservation and Management of Highly Migratory Fish Stocks in the Western and Central Pacific Ocean 2000 (Honolulu, 5 September 2000, in force 19 June 2004). Available at http://www.wcpfc.int/doc/convention-conservation-and-management-highly-migratory-fish-stockswestern-and-central-pacific

${ }^{105}$ See IATTC, NPFC, SPRFMO, WCPFC, and WECFC.
} 
environment. ${ }^{106}$ Transparency of decision-making and availability of information also vary qualitatively. ${ }^{107}$ Indeed, IUCN has noted that 10 out of 13 RFMOs made no open access to primary data available. ${ }^{108}$ This is despite Article 12 of the FSA requiring transparency in decision-making and 'other activities'. Only a few RFMBs explicitly adopt strong guarantees of transparent decision-making. ${ }^{109}$ Similarly, whilst most RFMBs support the dissemination of information and decisions, few indicate that this will be done publicly. Often key information on enforcement and compliance is unreported, undermining compliance culture within RFMOs. ${ }^{110}$ Others include caveats about confidentiality. ${ }^{111}$ Arguably this falls short of best practice, for example, as included within the Aarhus Convention. ${ }^{112}$ Despite being a euro-centric regime, little percolation of requirements of openness and transparency into other RFMOs in which European States and the EU participate appears to have occurred. ${ }^{113}$ References to sustainable use of resources are common. However, few references to equitable sharing of resources exist. ${ }^{114}$ SIOFA is perhaps an exception, in that it refers to the special position of small island and other developing States. Whilst debates have taken place about the application of the CHM principle to MGR, it cannot be conceived that this would have any direct influence on fisheries. There is no such reference to this in any fisheries instrument and no State is advancing this view. That said, it is possible that an IA with provisions on benefit-sharing and capacity-building might influence some RFMOs to adopt more 'equitable' arrangements for access to fisheries. The way in which the principles are articulated varies considerably.

In general, the extent to which principles are found in agreements depends on a range of factors. Thus post-1995 agreements (including those amended since 1995) have tended to a stronger and more complete statement of principles as per the FSA. It is unsurprising that RFMOs, as opposed to advisory bodies, have stronger provisions on the use of science, data exchange, and co-operation. Several of these principles/approaches exist under general international law, and therefore apply to activities within ABNJ regardless of their inclusion within an RFMO constituent agreement. However, their inclusion would have symbolic value and arguably increase pressure on States and other RFMOs to implement measures consistent with these principles. Finally, this short review focuses on the constituent instruments. In

${ }^{106}$ See the evaluation of ecological risk assessment conducted by the IUCN: E Gilman, K Passfield and K Nakamura, Performance Assessment of Bycatch and Discards Governance by Regional Fisheries Management Organizations (IUCN, Gland, 2012), section 4.3.

${ }^{107}$ See T McDorman, 'Implementing Existing Tools: Turning Words into Action - Decision-Making Processes of Regional Fisheries Management Organizations' (2005) 20(3) IJMCL 423-457, at 428.

${ }^{108}$ Supra (n 106), section 4.2.

${ }^{109}$ I.e., CECAF, ICCAT and IOTC.

${ }^{110}$ Supra (n 106), section 4.5.

${ }^{111}$ See for example, Convention on the Conservation and Management of Fishery Resources in the South East Atlantic Ocean 2001 (Windhoek, 20 April 2001, in force 13 April 2003), 2221 UNTS 189, Art. 6(3)(1). Available at http://www.seafo.org/About/Convention-Text

${ }^{112}$ Convention on Access to Information, Public Participation in Decision-making and Access to Justice in Environmental Matter 1998 (Aarhus, 25 June 1998, in force 30 October 2001), 2161 UNTS 447.

${ }^{113}$ The EU is a member of six tuna/highly migratory species RFMOs (AIDCP, CCSBT, IATTC, ICCAT, IOTC, and WCPFC) and 11 mixed RFBs (CCAMLR, Convention on the Conservation and Management of Pollock Resources in the Central Bering Sea (CCBSP), CECAF, GFCM, NAFO, North Atlantic Salmon Conservation Organization (NASCO), NEAFC, SEAFO, SIOFA, SPRFMO and WECAFC).

${ }^{114}$ See the fifth recital of the preamble to the Convention on the Conservation and Management of High Seas Fishery Resources in the South Pacific Ocean 2009 (Auckland, 14 November 2009, in force 24 August 2012). Available at http://www.sprfmo.int/assets/Basic-Documents/Convention-web.pdf 
recent years several RFMOs have started to adopt formal cross-sectoral mechanisms, not just with other fisheries bodies, but also with institutions responsible for environmental issues. ${ }^{115}$ This may establish pathways leading to more sophisticated management mechanisms, such as ABM and comprehensive EIAs.

\section{Fisheries and ABM}

$\mathrm{ABM}$ is a collective term referring to a range of spatially determinate measures designed to prevent harm to the environment, conserve resources and/or coordinate activities. From the outset, there has been consensus that ABM tools, including a network of MPAs and associated fisheries measures, are important tools for conserving and managing marine biodiversity in ABNJ. ${ }^{116}$ Initially, there appeared to be general support by States for addressing fisheries within ABM regimes. ${ }^{117}$ Already several RFMOs (and other institutions: ISA, International Maritime Organization (IMO)) adopt some form of ABM, so the question is really about whether this requires better coordination of these or entirely new mechanisms. ${ }^{118}$ However, the 2006 BBNJ meeting was silent on both the legal basis of and institutional support for ABM. Delegations have since adopted quite different positions on this. When this issue was raised in 2008, some delegations noted that a more comprehensive and integrated approach than currently existed was required. ${ }^{119}$ Some delegations have noted that measures to protect spawning stocks or to establish catch or fishing limits for specific areas are a form of ABM. ${ }^{120}$ Other delegations argued that progress needed to be made within existing arrangements, including RFMOS. ${ }^{121}$ In 2010 , other delegations noted that existing RFMOs and arrangements have a mandate to implement ABM tools, such as MPAs, both in relation to particular stocks and the effects of fishing activities on vulnerable marine ecosystems in the high seas. ${ }^{122}$ Reference was made to the MOU between NEAFC and OSPAR as an example of how existing institutions could cooperate in developing ABM tools. ${ }^{123}$

In 2012, questions remained about the scope of MPA: what activities would be allowed therein, such as fisheries, and what role should existing institutions, such as RFMOs, have as regards MPAs. ${ }^{124}$ By 2014, it appeared that the issue was becoming polarized: was a new global instrument required to secure effective ABM, or could this be achieved through existing regional and sectoral regimes? Noting the absence of any global regime for MPAs, one suggestion was to develop a regional framework for the designation and implementation of MPAs, following the RFMO/FSA model. ${ }^{125}$ However, it was not clear whether this would be done through ad hoc arrangements or a coordinating instrument. As regional cooperation may be easier to secure than global agreement, and would allow for regional circumstances to be taken

\footnotetext{
${ }^{115}$ Supra (n 91), and accompanying text.

${ }^{116}$ UN Doc. A/61/65, para 59 and Annex I, para 10.

117 Ibid., Annex I, para 10.

118 See Takei, supra (n 51), chapter 3.

${ }^{119}$ UN Doc. A/63/79, para 28.

${ }^{120}$ UN Doc. A/65/69, para 66.

${ }^{121}$ UN Doc. A/63/79, para 30.

122 UN Doc. 69/117*, para 25.

${ }^{123}$ UN Doc. A/65/68, para 59. More specifically, the MOU refers to cooperation between NEAFC and OSPAR regarding marine spatial planning and ABM. Supra (n 91), at point 1(d).

${ }^{124}$ UN Doc. A/67/95, para 31.

${ }^{125}$ UN Doc. A/69/82, paras 59-60.
} 
into account, one can see the attraction of this approach. However, one must also consider that regional fisheries are predominantly concerned with areas within national jurisdiction and they as yet do not provided complete geographic coverage. Discussions at the second meeting of the BBNJ in 2014 are revealing as to the complexities of designating and managing ABM regimes in ABNJ. First, it was generally agreed that although existing mechanisms exist for $\mathrm{ABM}$, these are neither plenary in scope, or fully developed and readily applicable to ABNJ. ${ }^{126}$ Second, in $\mathrm{ABNJ}$, the principal form of jurisdiction is by the flag State, and this means that the effectiveness of ABM is contingent on widespread global support. ${ }^{127}$ This is precisely the same challenge facing existing RFMOs and one that any new regime will need to address.

It is not clear that significant progress was made at PrepCom on the relationship between fisheries and ABM. At a bare minimum, all States seemed to agree that some degree of coordination is required between an instrument containing ABM provisions and existing fisheries regimes. Several delegations suggested that the development of ABM should draw upon or involve RFMOS. ${ }^{128}$ The African Group rightly emphasized that RFMOs cannot adopt an integrated approach to MPAs - this requires, at a minimum, coordination of efforts. ${ }^{129}$ New Zealand and the US support inclusion of fisheries in a legally binding instrument. ${ }^{130}$ However, there seemed to be little appetite for a significant revision of RFMO mandates. Norway noted the cost-effectiveness of relying on existing mechanisms, such as RFMOs to establish MPAs. ${ }^{131}$ New Zealand proposed setting criteria for ABM tools that could be used by RFMOs. ${ }^{132}$ This approach has could be effective, having been relatively successful with regard to the FSA, which influenced the standards and mandates of pre-existing RFMOs, as well as newly established RFMOs. ${ }^{133}$ Furthermore, Norway noted the cost-effectiveness of relying on existing mechanisms, such as RFMOs to establish MPAs. ${ }^{134}$ Following calls from Iceland, Japan and the Russian Federation to hear from RFMOS, it seems likely that RFMOs will be more actively engaged in subsequent meetings of PrepCom. ${ }^{135}$

If the proposed ABNJ IA is to include provisions on ABM, then this should be done consistently with existing legal instruments providing for ABM. ${ }^{136}$ The LOSC,

\footnotetext{
${ }^{126}$ UN Doc. 69/117*, paras 59-62.

127 Ibid., at para 64.

${ }^{128}$ Australia, the EU, Papua New Guinea and the United States, Earth Negotiations Bulletin, (2016) vol. 25/102, pp. 1-2.

${ }^{129}$ Ibid., at p. 1.

${ }^{130}$ Ibid.

${ }^{131}$ Earth Negotiations Bulletin, (2016) vol. 25/99, p. 2.

132 Earth Negotiations Bulletin, (2016) vol. 25/102, p. 1.

${ }^{133}$ See D Diz Pereira Pinto, Fisheries Management in Areas beyond National Jurisdiction. The Impact of Ecosystem Based Law Making (Martinus Nijhoff, Leiden, 2013), chapter 5.

${ }^{134}$ Earth Negotiation Bulletin, (2016) vol. 25/99, p. 2.

${ }^{135}$ Ibid., at p. 2.

136 Other relevant mechanisms include: Whaling sanctuaries under Art $\mathrm{V}(1)$ of the International Convention for the Regulation of Whaling 1946 (Washington, 2 December 1946, in force 10 November 1948), 161 UNTS 72; Special Areas under Annexes I, II and V of International Convention for the Prevention of Pollution from Ships 1973 (London, 2 November 1973), as amended by Protocol of 1978 relating to the International Convention for the Prevention of Pollution from Ships of 1973 (London, adopted 17 February 1978, in force 2 October 1983) (MARPOL 73/78), 1340 UNTS 62; Particularly Sensitive Sea Areas (PSSA), as outlined in IMO Resolution A. 720(17) and revised in IMO Resolution A.927(22); Specially Protected Areas of Mediterranean Interest under the Protocol to the Barcelona Convention. See further T Scovazzi, 'Marine Protected Areas on the High Seas: Some Legal and Policy Considerations' (2004) 19(1) IJMCL 1-17.
} 
the FSA and the FAO Code of Conduct for Responsible Fisheries contain a limited range of provisions relevant to $\mathrm{ABM},{ }^{137}$ but these are only obligations of a general nature, falling someway short of stronger ABM exemplified by, for example, the EU Habitats Directives or Maritime Spatial Planning regimes. ${ }^{138}$ The most important agreement is the Convention on Biological Diversity, Article 8 of which encourages Contracting Parties to establish a system of protected areas as part of their commitments to 'in situ' conservation of biodiversity. ${ }^{139}$ As appropriate, guidelines should be adopted for the selection, establishment and management of such areas, along with regulatory or management measures. These general commitments were further developed through the Programme of Work on Marine and Coastal Biodiversity. ${ }^{140}$ Such policy measures are principally focused on areas within national jurisdiction, although the Programme highlighted the importance of cooperation, information-gathering and the adoption of measures consistent with international law to protect biodiversity in ABNJ. ${ }^{141}$ These measures are generally predicated upon the adoption of nationality/flag State measures. Measures of general application can only be secured through multilateral agreements. ${ }^{142}$

Some RFMOs utilize area-based management tools. In 2006, the GFCM declared three areas as Fisheries Restricted Areas to protect corals, cold hydrocarbon seeps and seamounts. In 2013, it adopted Resolution GFCM/37/2013/1, which seeks to establish and coordinate Fisheries Restricted Areas with Specially Protected Areas of Mediterranean Importance (SPAMIs), with a particular focus on high seas areas. ${ }^{143}$ NEAFC has introduced closed areas in ABNJ, including Hatton and Rockall Banks, to bottom trawling and static gear in order to protect vulnerable marine ecosystems. ${ }^{144}$ NAFO has established two closed areas to shrimp fisheries on the Flemish Cap. ${ }^{145}$ In 2007, four seamount areas were closed to bottom fishing between 2007 and 2010, ${ }^{146}$ and two further areas were closed in 2008. ${ }^{147}$ A coral protection zone was established in 2008, which is also closed to bottom-gear fishing. ${ }^{148}$ Following the adoption of

137 See LOSC, Arts. 192, 194(5), FSA Arts. 5 and 6; FAO Code, Art. 10.1.1. Available at http://www.fao.org/docrep/005/v9878e/v9878e00.htm.

${ }^{138}$ See further R Long, 'The Marine Strategy Framework Directive: A New European Approach to the Regulation of the Marine Environment, Marine Natural Resources and Marine Ecological Services' (2011) 29(1) Journal of Energy and Natural Resources Law 1-44.

${ }^{139}$ Convention on Biological Diversity 1992 (Rio de Janeiro, 5 June 1992, in force 29 December 1993), 1760 UNTS 79. Under Art. 4(2), States can take measures as regards processes and activities beyond national jurisdiction. However, this would fall short of true ABM, as such measures are limited to control over nationals. As such they could only supplement true ABM through other measures.

${ }^{140}$ COP 7 (2003) Decision VII/5. Available at https://www.cbd.int/decision/cop/?id=7742

${ }^{141} \mathrm{Ibid}$., at paras, 54-62, and Objectives 2.1, 2.2, 2.4 and 3.2.

${ }^{142}$ See further EJ Molenaar and AG Oude Elferink, 'Marine protected areas in areas beyond national jurisdiction. The pioneering efforts under the OSPAR Convention' (2009) 5(1) Utrecht Law Review 520.

${ }^{143}$ Resolution GFCM/37/2013/1 on ABM of fisheries, including through the establishment of Fisheries Restricted Areas (FRAs) in the GFCM Convention area and coordination with the UNEP-MAP initiatives on the establishment of SPAMIs. Available at http://www.fao.org/3/a-ax392e.pdf.

${ }^{144}$ Recommendation IX:2008. These measures have since been continued: See Recommendation VIII:2010; Recommendation 14:2011; Recommendation 8:2012; Recommendation 19:2014. Available at http://www.neafc.org/managing_fisheries/measures

145 NAFO Conservation and Enforcement Measures 2006, NAFO FC/ Doc 06/1, art 12. This and subsequent NAFO measures are available at http://www.nafo.int/fisheries/frames/fishery.html

146 This includes the Orphan Knoll, Corner Seamounts, Newfoundland Seamounts and New England Seamounts NAFO Conservation and Enforcement Measures 2007, NAFO FC/ Doc. 07/1, Art. 12.

${ }^{147}$ Fogo Seamount Areas 1 and 2. See NAFO Conservation and Enforcement Measures 2009, NAFO FC/ Doc. 09/1, Art. 15.

${ }^{148}$ NAFO Conservation and Enforcement Measures 2008, NAFO FC/ Doc. 08/1, Art. 15. 
conservation and management measures in 2015, there are now 13 areas closed to bottom fishing, six protected seamount areas, and one Coral Area Closure Zone. ${ }^{149}$ Since 2006, SEAFO has closed a number of vulnerable marine areas to fishing. At present, 11 areas are closed to all fishing and one area to all fishing except pots and longlines. ${ }^{150}$ In the Indian Ocean, the Southern Indian Ocean Deepsea Fishers' Association, which is comprised of the four main bottom-trawling companies in the region, has designated 13 Benthic Protected Areas (BPAs). BPAs are areas where bottom trawling and dredging is forbidden. However, these measures are limited to members; they cannot be imposed upon third-party operators. There is also little independent assessment, oversight or control of the designations.

The FAO's International Guidelines for the Management of Deep-Sea Fisheries in the High Seas promote the use of area-based management in vulnerable marine ecosystems (VMEs). ${ }^{151}$ The Guidelines encourage both States and RFMOs to identify and designate VMEs. ${ }^{152}$ VMEs should be closed to fishing "until appropriate conservation and management measures have been established to prevent significant adverse impacts on VMEs and ensure long-term conservation and sustainable use of deep-sea fish stocks..." The Guidelines do not establish formal legal authority to manage fisheries. Indeed, they note the limits of existing institutional arrangements and call upon States to strengthen this. ${ }^{153}$ The ABNJ IA could provide an opportunity to strengthen the legal basis for such measures. That said, marine ABM principles tend to be discretionary and facilitative for good reason: management should be adaptive and context-specific. The importance of flexibility suggests that it is unlikely that the prospective ABNJ IA will depart from this approach - perhaps preferring the exhortation of guiding principles and approaches. The absence of detailed provisions on marine ABM means that the ABNJ IA is unlikely to generate acute legal conflicts with existing legal arrangements unless it adopts measures that run counter to fundamental principles of exclusive flag State jurisdiction in ABNJ. Herein lies the crux of the matter, as it is precisely this response to a lack of strong coordinated/centralized institutional management that is driving the ABNJ process. Detailed discussion of such issues was notably absent from the BBNJ meetings and PrepCom. Careful steps will need to be taken to secure the agreement on coordinated management within a system where the political preference is for decentralized Statecentric decision-making.

\section{Fisheries and EIA}

EIA is a procedural tool used in many legal systems to ensure that the potential adverse environmental effects of an activity are understood before a decision is made

\footnotetext{
${ }^{149}$ NAFO Conservation and Enforcement Measures 2015, NAFO FC/ Doc. 15/1, Art. 17. It is notable that two of these sites cover areas in the Sargasso Sea, combining the notion of VME and ecologically significant marine areas under the CBD. See further D Diz, 'The Seamounts of the Sargasso Sea: Adequately Protected?' (2016) 31(2) IJMCL 359-70.

${ }^{150}$ Conservation Measure 30/15 on Bottom Fishing Activities and Vulnerable Marine Ecosystems in the SEAFO Convention Area. Available at http://www.seafo.org/Management/Conservation-Measures

${ }^{151}$ FAO, International Guidelines for the Management of Deep-Sea Fisheries in the High Seas (FAO, Rome, 2009).

${ }^{152}$ Ibid., paras 21(ii) and 42-53.

${ }^{153}$ Ibid., paras 26-28.
} 
to authorize it. The duty to conduct an EIA is part of customary international law. ${ }^{154}$ However, it is questionable whether or not this applies to existing and/or new fisheries. It also unclear the extent to which fisheries should be included within an EIA resulting from other non-fishing activities. The LOSC does not contain a specific provision requiring an EIA for fisheries; instead, it establishes under Article 206 a rather basic requirement to consider the impacts of an activity when a State has reasonable grounds to believe that it may cause substantial pollution or significant harm to the environment. ${ }^{155}$ Article 206 falls short of requiring a cross-sectoral, cumulative EIA that appears to be necessary in ABNJ, although it does not necessarily prevent this. It also elides reference to strategic EIAs. Article 6(6) of the FSA requires assessment of new or exploratory fisheries, but this occurs only after the fishing has begun.

Given that fishing is considered to be a significant cause of biodiversity loss, it is no surprise that the connection between EIAs and fisheries was raised on several occasions during the BBNJ and PrepCom discussions. ${ }^{156}$ In 2006, the BBNJ noted the potential for a new agreement to address the fragmentation and sectoral approaches and provide for the possibility of cumulative EIAs. ${ }^{157}$ At the 2008 meeting, some delegates suggested that the approach taken in UNGA Resolution $61 / 105$ to the assessment of impacts on fishing could be used as one model for EIA. ${ }^{158}$ However, this suggests a non-binding commitment, and one that lacks the detail and structure required to undertake an effective EIA. As noted in some later debates, such obligations already exist under international law. ${ }^{159}$ However, the quality of such obligations varies considerably across different sectors, and within fisheries instruments they tend to be quite general or non-binding. ${ }^{160}$ In 2011, the development and implementation of procedures to assess the impact of activities, including fisheries, was proposed. ${ }^{161}$ Thereafter, the discussion was focused on specific

154 See Case concerning Pulp Mills on the River Uruguay (2010) ICJ Rep 14, para 204; Responsibilities and obligations of States with respect to activities in the Area, Advisory Opinion, 1 February 2011, ITLOS Reports 2011, p. 10, para 145.

155 See further, AG Oude Elferink, 'Environmental Impact Assessment in Areas beyond National Jurisdiction' (2012) 27(2) IJMCL 449-480; D Ma, Q Fang and S Guan, 'Current legal regime for environmental impact assessment in areas beyond national jurisdiction and its future approaches' (2016) 56 Marine Policy 23-30.

156 See comments at PrepCom by Australia and Papua New Guinea noted in Earth Negotiations Bulletin, (2016) vol. 25/102, p. 2; and Norway, Earth Negotiations Bulletin, (2016) vol. 25/103, p 1.

${ }^{157}$ UN Doc. A/61/65, para 55.

${ }^{158}$ UN Doc. A/63/79, para 18, referring, it appears, to UNGA Res. 61/105, para 83. A similar reference was made in 2011 to UNGA Res. 64/72 concerning the impact of bottom fisheries on VMEs. This Resolution contains far more detailed provisions on EIA, but is still only guidance. UN Doc. A/66/119, para 54.

${ }^{159}$ UN Doc. A/65/68, paras 52 and 56. Specific reference was made to LOSC Articles 205-6, the CBD and the FSA. More generally, see the Convention on Environmental Impact Assessments in a Transboundary Context 1991 (Espoo, 25 February 1991, in force 10 September 1997), 1989 UNTS 389, and the Protocol on Strategic Environmental Assessment to the Convention on Environmental Impact Assessment in a Transboundary Context 2003 (Kyiv, 21 February 2003, in force 11 July 2010), 2685 UNTS 140. Non-binding instruments include: UNEP Goals and Principles of Environmental Impact Assessment, UNEP Res. GC 14/25, $14^{\text {th }}$ Sess (1987); Voluntary Guidelines on BiodiversityInclusive Impact Assessment, UNEP/CBD/COP/DEC/VIII/28, 15 June 2006; and the Voluntary Guidelines for the Consideration of Biodiversity in Environmental Impact Assessments and Strategic Environmental Assessments in Marine and Coastal Areas, UNEP/CBD/SBSTTA/16/7/Add.1, 11 April 2012.

${ }^{160}$ See for example Art. 5(c) of the Fish Stocks Agreement, and the FAO, International Guidelines for the Management of Deep-Sea Fisheries in the High Seas, supra (n 151).

${ }^{161}$ UN Doc. A/66/119, para 31. 
questions including: whether a new agreement would address the lack of political will for expanding the scope of EIA, who would conduct and monitor EIAs in ABNJ, whether uniform standards could be agreed, and how the cumulative impacts of multiple stressors from different sectors would be addressed in any EIA process. ${ }^{162}$

Some progress on environmental assessment was made at PrepCom. At a minimum, it was recognized that the LOSC provides only a general framework, and there is a need to develop common or minimum standards as regards the content of EIAs. ${ }^{163}$ The Chair's summary of discussions simply maps out in some detail a wide range of features of EIAs, but without indicating how EIA will actual develop. ${ }^{164}$

Despite the existence of a customary duty to conduct an EIA, this only becomes meaningful if the procedures for the EIA are then properly articulated within a legal instrument. As indicated in Table 1, the FSA and some RFMOs address EIA, albeit in quite general terms. This does not go far enough. Elferink notes that the lack of EIA for fisheries is due to fisheries having developed in parallel to environmental law, as opposed to being part of it. ${ }^{165}$ If the prospective IA is to make a difference, then it will need to move beyond generalities and articulate a meaningful EIA process. Support for this has been emerging through non-binding instruments, and it is possible that the processes outlined therein may evolve into formally binding rules. In 2006, the UNGA called States and RFMOs to conduct EIA prior to new fisheries in ABNJ. Paragraph 83(a) of UNGA Resolution 61/105 calls upon RFMOs "To assess, on the basis of the best available scientific information, whether individual bottom fishing activities would have significant adverse impacts on vulnerable marine ecosystems, and to ensure that if it is assessed that these activities would have significant adverse impacts, they are managed to prevent such impacts, or not authorized to proceed". Such an EIA provides a starting point for the adoption of other management measures, including ABM tools for VMEs. This was reiterated in UNGA Resolution 64/72 of 2009, which called for implementation of UNGA Resolution 61/105 by flag states and RFMOs in accordance with the FAO Guidelines on Deep Sea Fisheries. Furthermore, they should "ensure that vessels do not engage in bottom fishing until such assessments have been carried out". ${ }^{166}$ Although a positive development, these measures have been criticized for being too weak. ${ }^{167}$ Limited EIAs have been produced or they are limited to specific features, such as corals or seamounts. States and RFMOs have been reluctant to close areas despite these EIAs. Instead, management measures are often limited to encounter protocols and 'move on' rules, which are set at too high a threshold to protect VMEs. ${ }^{168}$ It is critical that

162 UN Doc. 69/117*, paras 66-70.

163 Earth Negotiations Bulletin, (2016) vol. 25/100, p. 2.

164 Supra (n 42), pp. 13-16.

165 Elferink, supra (n 155), p. 469.

166 UN Doc. A/Res/64/72, para 119(a).

${ }^{167}$ See M Gianni, DEJ Currie, S Fuller, L Speer, J Ardron, B Weeber, M Gibson, K Sack, and A Kavanagh, Unfinished business: a review of the implementation of the provisions of UNGA resolutions 61/105 and 64/72 related to the management of bottom fisheries in areas beyond national jurisdiction (Deep Sea Conservation Coalition, September 2011). Available at http://www.savethehighseas.org/publicdocs/dscc_review11.pdf. See also the report of the UN GA Workshop to discuss implementation of paragraphs 80 and 83 to 87 of Resolution 61/105 and paragraphs 117 and 119 to 127 of Resolution 64/72 on sustainable fisheries, addressing the impacts of bottom fishing on vulnerable marine ecosystems and the long-term sustainability of deep-sea fish stocks: Letter dated 27 October 2011 from the Moderator of the Workshop to the President of the General Assembly. UNGA Doc. A/66/566 (18 November 2011).

168 'Encounter protocols' require vessels that bring up a particular quantity of species, e.g., live coral or sponges, in their gear to 'move on' to a different fishing area. See Gianni et al., ibid. 
insufficient controls have been placed on bottom trawling. If guidelines are currently unable to secure effective protection of valuable or important resources, then a stronger legally binding regime is necessary. Although EIA is generally required of States, it needs to be linked to an effective decision-making process. Ideally, where there are reasonable grounds to believe that harm may occur, an EIA must be a prerequisite to fishing activities taking place. No EIA should mean no fishing. However, it may be observed that at the resumed Review Conference of the FSA 2010, States adopted quite varied positions on this, with some rejecting the requirement of prior EIAs, ${ }^{169}$ and others calling for a judicious use of EIAs. ${ }^{170}$ Underlying this is a concern about the burdens that might be placed on the fishing industry. Such concerns are not unimportant, given that other, arguably wealthier sectors, such as commercial shipping, are not under similar pressures to conduct EIAs.

It may also be observed that many fisheries are established practices and it is commonplace for EIA only to apply to new activities. Some RFMOs have adopted the requirement for prior EIA for new fisheries. CCAMLR has led on this, requiring Contracting Parties to notify the Scientific Committee and submit a preliminary EIA. ${ }^{171}$ Contracting Parties shall not authorize vessels flying their flag to participate in bottom-fishing without approval of the Commission. ${ }^{172}$ Since 2014, NEAFC has required prior EIA of exploratory bottom-fishing in VMEs. ${ }^{173}$ This approach has been replicated by SEAFO. ${ }^{174}$ Exploratory bottom-fisheries in the NAFO regulatory area are subject to a preliminary EIA prior to authorization. ${ }^{175}$ To reiterate, such EIAs are limited to new and exploratory fisheries. An exception to this is the SPRFMO. Since 2014, it has required that all bottom fishing activities undergo an EIA prior to approval. ${ }^{176}$ Such measures do not require a new mandate under an ABNJ IA. However, it is arguable that they will be limited in their ability to deliver strategic or integrated EIA of fishing and other activities in ABNJ. In this respect, an IA could do much to advance and structure the conduct of strategic EIAs (SEAs). ${ }^{177}$

SEAs are "formalized, systematic and comprehensive processes of identifying and evaluating the environmental consequences of proposed policies, plans or programmes to ensure that they are fully included and appropriately addressed at the earliest possible stage of decision-making on a par with economic and social

\footnotetext{
${ }^{169}$ Iceland is reported to have objected to such a proposal by Greenpeace: See Earth Negotiations Bulletin, (2016) vol. 7/65, p. 7.

${ }^{170}$ Ibid.

${ }^{171}$ Conservation Measure 21-01 (2010) Notification that Members are considering initiating a new fishery; Conservation Measure 22-05 (2008) Restrictions on the use of bottom trawling gear in highseas areas of the Convention Area. Available at https://www.ccamlr.org/en/conservation-andmanagement/browse-conservation-measures

${ }_{172}$ Para 6 of CM 22-05, ibid.

${ }^{173}$ Recommendation 19 2014: Protection of VMEs in NEAFC Regulatory Areas as Amended by Recommendation 09:2015, Available at http://www.neafc.org/managing_fisheries/measures/current

${ }^{174}$ See Conservation Measure 30/15 on Bottom Fishing Activities and Vulnerable Marine Ecosystems in the SEAFO Convention Area. Supra (n 150)

${ }^{175}$ NAFO Articles 18 to 20 of Conservation and Enforcement Measures of 2015, and Annex I.E. Available at http://www.nafo.int/fisheries/frames/fishery.html

${ }^{176}$ Conservation and Management Measure for the Management of Bottom Fishing in the SPRFMO Convention Area (CMM 2.03). Available at https://www.sprfmo.int/cmms/

${ }^{177}$ R Warner, 'Oceans beyond Boundaries: Environment Assessment Frameworks' (2012) 27(2) IJMCL 481-499.
} 
considerations". ${ }^{178}$ A SEA is usually conducted by a public authority, as opposed to an EIA, which is triggered and driven by a private developer/actor. The SEA is intended to provide a broader framework for assessing a range of activities and may be better suited to integrating a wider range of factors into the EIA. As such it can be used to guide individual project/activity-level EIAs and decisions. In this sense the SEA and EIA are complementary and help ensure a more balanced consideration of public/private concerns. However, this approach presents some difficulties when transposed to the international level where States are both sponsors and decisionmaking authorities. Existing instruments place the responsibility in the hands of individual States. ${ }^{179}$ Ideally, there should be some degree of externality to the SEA, otherwise the evaluation process will lack independence and legitimacy. Furthermore, it is arguable that individual States are not in the best position to conduct SEA for plans and programmes of activities that are actually set within regional or international bodies like RFMOs or the ISA. Here it would be logical for SEA to be carried within that forum or through some other cross-cutting institutional mechanism. This would have the benefit of being inclusive of cumulative and interrelated activities, and could fit within current RFMO strategic planning activities. Whilst this could be burdensome, and it would not remove the need for individual EIAs, this approach, if done carefully, could reduce the burden on individual States or agencies responsible for conducting project-specific EIAs. This approach would be contingent on ensuring that individual EIAs take account of the SEA.

\section{Pathways to Reform of Fisheries in ABNJ}

Given the novelty of the topic, little has been written on the scope and content of the proposed IA. ${ }^{180}$ Fortunately, as the above analysis indicates, a more extensive array of literature exists on the governance of $\mathrm{ABNJ}$, which explores regulatory/governance gaps, maps out governance principles, and investigates specific regulatory options, such as ABM and EIA. Such literature provides fertile ground for speculation as to the potential shape and form of an IA on ABNJ.

Discussions at the BBNJ and PrepCom show that the challenge is not so much in identifying the relevant legal principles; these are well known and generally accepted. The greater challenge is to overcome current institutional limitations, where the decentralized nature of the international legal order presents particular challenges for the adoption of integrated approaches and the use of spatial or crosscutting tools like ABM and EIA. There is considerable scope to develop and learn from existing regimes. ABM and EIA are well developed within domestic law and this can provide models for a legally binding instrument on ABNJ. Domestic regimes are notably moving towards greater integration both within ABM and EIA regimes, and across different regulatory approaches. For example, marine spatial planning at the domestic and regional level increasingly takes account of all activities occurring within marine spaces, and, at an EU level, across different jurisdictions. This is already influencing practices at a regional level through OSPAR and NEAFC, where

\footnotetext{
${ }^{178}$ B Sadler and R Verheem, Strategic Environmental Assessment. Status, challenges and future directions. Report No 53 (Ministry of Housing, Spatial Planning and the Environment, The Hague, The Netherlands, 1996), 27.

${ }^{179}$ Articles 3, 4 and 10 of the SEA Protocol to the Espoo Convention, supra (n 159).

${ }^{180}$ See Long and Chaves, supra (n 11); Warner, supra (n 40). Also S Hart, Elements of a Possible Implementation Agreement to the LOSC for the Conservation and Sustainable Use of Marine Biodiversity in Areas beyond National Jurisdiction (IUCN, Gland, 2008).
} 
MOUs are in place to facilitate information sharing and coordination of activities. As a minimum, an ABNJ IA should encourage and structure such practices.

Fisheries did not feature explicitly in the original list of topics to be addressed in an IA. However, this is not the end of the matter. If it is to succeed, a comprehensive, legally binding instrument on marine biological diversity must deal with fisheries either directly or indirectly, through the mandating of strong cooperative mechanisms within existing institutional regimes. The case for the inclusion of fisheries is strong, given the importance States have attached to integrated/ecosystem-based approaches, and when considering the practical impact of $\mathrm{ABM}$ on fisheries or the need to account for the impact of fisheries when assessing cumulative impacts on the marine environment. The case against the inclusion of fisheries largely rests on the existence of a dedicated regime for fisheries through the FSA and various RFMBs. There appears to be no appetite for wholesale reform of RFMOs. The path of compromise is likely to see States address fisheries in ABNJ indirectly, through the development of principles of general application and the creation of more carefully structured cooperative mechanisms. This may follow a similar approach to that adopted in the FSA. Ultimately this may result in some moderate reform of RFMOs. This may help address some governance gaps. However, it will not result in significant change in the structure and authority of fisheries arrangements. This is likely to be reinforced through carefully drafted savings and compatibility clauses within an ABNJ IA.

It is important not to regard the proposed ABNJ IA as a panacea and to overburden it with expectations. In particular, efforts to addresses RFMO gaps in species and geographic coverage ought to be pursued through other fora, albeit influenced by discussions taking place during the UN's ABNJ process. Regardless of the direction that discussions on fisheries take at PrepCom, it is clear that developments will continue apace outside of the UN process. Already during the debates in the BBNJ, particular emphasis was placed on UNGA Resolution 61/105, which addressed the impacts of bottom fishing on VMEs (including ABNJ), and the work of the FAO in developing international guidelines on the management of deepsea fisheries. ${ }^{181}$ Furthermore, since the BBNJ Working Group first met, the following instruments have been adopted: FAO International Guidelines on the Management of Deep-sea Fisheries in the High Seas in $2008^{182}$ and the Convention on the Conservation and Management of High Seas Resources in the South Pacific Ocean (I 2009. ${ }^{183}$ The FAO Agreement on Port State Measures to Prevent, Deter and Eliminate Illegal, Unreported and Unregulated Fishing was adopted in 2009 and entered into force on 5 June 2016. ${ }^{184}$ Looking forward, there will be ongoing consideration of issues related to ABNJ during the Review Conferences of the FSA and at the Subsidiary Body on Scientific, Technical and Technological Advice of the CBD. At a regional level, conservation and management measures taken by RFMOs will continue to adapt to the complex socio-ecological realities of ABNJ. These fora and initiatives provide fertile grounds for cross-fertilization of ideas and approaches. Over the next couple of years they will inevitably influence the way in which fisheries issues are handled during PrepCom and the subsequent ABNJ IA negotiations.

\footnotetext{
${ }^{181}$ See UNGA Resolution 61/105, paras 82-90.

182 Supra (n 151).

183 Supra (n 114).

${ }^{184}$ Available at http://www.fao.org/3/a-i1644t.pdf.
} 